Discussion Paper Series A No.629

\title{
Marriage and Economic Development in the Twentieth Century
}

\author{
Alessio Moro \\ (University of Cagliari) \\ Solmaz Moslehi \\ (Monash University) \\ and \\ Satoshi Tanaka \\ (University of Queensland)
}

October, 2015

Institute of Economic Research

Hitotsubashi University

Kunitachi, Tokyo, 186-8603 Japan 


\title{
Marriage and Economic Development in the Twentieth Century*
}

\author{
Alessio Moro ${ }^{\dagger}$ \\ University of Cagliari
}

\author{
Solmaz Moslehi ${ }^{\ddagger}$ \\ Monash University
}

October 20, 2015

\author{
Satoshi Tanaka ${ }^{\S}$ \\ University of Queensland
}

\begin{abstract}
There is an extensive literature discussing how individuals' marriage behavior changes as a country develops. However, no existing data set allows an explicit investigation of the relationship between marriage and economic development. In this paper, we construct new cross-country panel data on marital statistics for 16 OECD countries from 1900 to 2000, in order to analyze such a relationship. We use this data set, together with cross-country data on real GDP per capita and the value added share of agriculture, manufacturing and services sectors, to document two novel stylized facts. First, the fraction of a country's population that is married displays a hump-shaped relationship with the level of real GDP per capita. Second, the fraction of the married correlates positively with the share of manufacturing in GDP. We conclude that the stage of economic development of a country is a key factor that affects individuals' family formation decisions.
\end{abstract}

${ }^{*}$ We thank Michele Boldrin, Nezih Guner, Diego Restuccia, José-Víctor Ríos-Rull and seminar participants at the University of Queensland, University of Technology Sydney, University of Sassari, University of Melbourne, Monash University, the Econometric Society North American Meeting (Minneapolis), Public Economic Theory (Seattle), the Southern Workshop in Macroeconomics (Auckland), the Summer School in Economic Growth (Capri), the V Workshop on Institutions, Individual Behavior and Economic Outcomes (Alghero), and the Workshop on Structural Change and Macroeconomic Dynamics (PSE) for the useful comments. Stojanka Andric provided excellent research assistance. This paper was previously titled Structural Change and the Rise and Fall of Marital Unions. The usual disclaimers apply.

†Contact: amoro@unica.it.

${ }^{\ddagger}$ Contact: solmaz.moslehi@monash.edu.au.

${ }^{\S}$ Contact: s.tanaka@uq.edu.au. 


\section{Introduction}

The evolution of marriage over the development path has attracted extensive attention from demographers, historians and, more recently, of economists (Becker (1981), Schoen, Urton, Woodrow, and Bai (1985), Fernández, Guner, and Knowles (2005), Stevenson and Wolfers (2007), Regalia, Ríos-Rull, and Short (2011), Chiappori, Salanié, and Weiss (2015) and Greenwood, Guner, Kocharkov, and Santos (forthcoming) among many others). As an economy develops, several changes can potentially influence individuals' marriage behavior. These are, for instance, changes in the living location (e.g. urbanization), in the level and the distribution of income, in employment opportunities for men and women, and in laws and institutions. Some of these changes are specific to a particular country, while others are shared by most countries along the process of economic development.

The purpose of this paper is to investigate how economic factors affect individuals' marriage behavior over the development path. Due to the fact that some of the determinants of marriage are specific to a certain country, this task requires data on multiple countries over time. Our first contribution in this paper is thus to construct a comprehensive, cross-country panel data set on marital statistics, which is suitable for our analysis. Existing data sets, such as the data on marriage and divorce created by the United Nations Statistical Division (UNSD) or the Minnesota Population Center's IPUMS International, only allow researchers to study marital statistics from 1950 for some countries and from 1970 for others. This creates a serious limitation for the analysis because at these dates, most OECD countries has already experienced a substantial part of their development process. Therefore, we use census records of each country directly collected from the country's national statistical office, to construct a sample of 16 OECD countries from 1900 to 2000, with data in 10-year intervals.

The second contribution of this paper is to use the constructed data set to analyze the evolution of marriage along the development path. For this purpose, we combine our data set with cross-country data of real GDP per capita, and investigate the relationship between marriage and real GDP per capita. To control for countries' heterogeneity, we run a fixed effects regression with the fraction of married population on the left-hand side and a polynomial of real GDP per capita on the right-hand side. Furthermore, for robustness, we employ a nonparametric plot of the fraction of the married over the level of real GDP per capita. Next, by using a similar methodology, we analyze the relationship between marriage rates and the value-added shares of broad sectors (agriculture, manufacturing and services) in GDP.

We highlight two main findings. First, we find that the fraction of the married displays 
a hump-shaped relationship with the level of GDP per capita. Although the literature has documented this hump shape by using U.S. time series data, the unavailability of long panel data didn't allow previous studies to find a general pattern across countries over the development path. ${ }^{1}$ With our unique data set, we confirm that the hump-shaped pattern of marriage is a common feature across OECD countries, and that it is driven by economic development, not by factors which are specific to the U.S. society. Second, we find that the fraction of the married correlates positively with the share of manufacturing in GDP. Sectoral shares represent the relative extent of each sector's economic activities in the whole economy, that evolve as a country develops. ${ }^{2}$ Our results suggest that, even controlling for individual countries' heterogeneity, the stage of development, and in particular the process of industrialization first and de-industrialization later, is a key dimension in determining the fraction of married individuals in the population.

The remainder of the paper is as follows: in Section 2, we discuss the construction of our data set; in Section 3, we provide the analysis of the relationship between marriage and economic development. Section 4 concludes.

\section{Construction of Historical Panel Data}

In this section, we describe the construction of our historical panel data for 16 OECD countries. Due to the short length of the time series in existing data sets on marriage, we directly obtained data from census records for most of the countries in our sample. The population data are then used to create marital statistics, which we combined with per-capita GDP and value-added shares of three sectors (agriculture, manufacturing, and the service sector). Since marital statistics are often affected by changes in the age structure of the population, we also create series that control for these effects. The remainder of the section describes the details of the data set.

\subsection{Data}

Our panel data consist of 16 OECD countries with 165 country-year observations. The main sources for our marriage data are population and housing census records, which are either

i) directly collected from each country's national statistical office, or ii) obtained from the

\footnotetext{
${ }^{1}$ Schoen, Urton, Woodrow, and Bai (1985) is the first paper which documents the pattern for the U.S. Recently, Greenwood and Guner (2008) and Iyigun and Lafortune (2015) have explored the economic reasons behind the hump-shaped change.

${ }^{2}$ Recent research such as that of Ngai and Pissarides (2007), Buera and Kaboski (2012a), and Herrendorf, Rogerson, and Valentinyi (2013) has studied the causes of the changes in sectoral shares over the development path.
} 
UNSD's database on marriage and divorce. ${ }^{3}$

Country Our country selection is based on the availability of a sufficiently long series of marriage data. Our sample consists of Australia, Belgium, Canada, Denmark, Finland, France, Germany, Italy, Japan, the Netherlands, Norway, Spain, Sweden, Switzerland, the U.K. and the U.S.

Time Period Given that marriage data in our sample are largely based on census records, they are in 10-year intervals (i.e., 1900, 1910, .., 2000). ${ }^{4}$ We choose the time period 1900-2000 for two main reasons. First, most of the OECD countries achieved economic development during that period;and, second, because data on marital statistics are not available prior to 1900 for the majority of those countries.

Marital Statistics Population data are collected by sex, age group, and 6 marital status groups (never-married, married, divorced, widowed, in a consensual union, and married but separated). ${ }^{5}$ From these population data, we construct marital statistics (fraction of the married, fraction of the never-married, and fraction of the divorced) for each country for each year. When constructing marital statistics, we take the following strategies: i) If the information on individuals in a consensual union is available, we include these individuals within the married group. ${ }^{6}$ ii) If the information on the separated is available, we include these individuals within the divorced group. We particularly take the latter strategy, because in some countries divorce was illegal for many years and, there were a non-negligible number of individuals who reported themselves as separated.

GDP Per Capita The data for real GDP per capita (in 1993 international dollar) are taken from Maddison (2005), similar to the approach taken by Buera and Kaboski (2012b). The data cover all the country-year observations in our panel.

\footnotetext{
${ }^{3}$ We utilize UNSD data when direct access to census records is not possible. UNSD collected statistics on marriage and divorce from the vital statistics system and population and housing censuses in each county's statistical office. For most of cases, UNSD's data are equivalent to country's census records. However, there are three observations which are the estimates UNSD created. For a complete description of the data sources for each country, see Appendix A.

${ }^{4}$ In some countries, censuses were not conducted exactly in 10-year intervals. When this is the case, we look for the closest year within 5 years before and after the year of concern. For example, if the data for 1950 are not available, we consider the available data collected in the year between 1945 and 1955 that is closest to 1950. We list data collection years for all countries in Appendix A.

${ }^{5}$ In some countries, divorce was illegal for many years in the first half of the century. The numbers of divorced individuals are, therefore, not reported. Also, in some other countries, the number of the divorced and that of the widowed are reported in the same category in the earlier periods. For a complete description about which types of marital status are reported, see Appendix A.

${ }^{6}$ The number of individuals in a consensual union is usually reported together with the married. Only in Canada and Norway in the year 2000, the number was reported separately from the married.
} 
TABle 1 - Descriptive Statistics for the Cross-Country Panel Data

\begin{tabular}{lccccc}
\hline Name of Series & $\begin{array}{c}\text { Num. of } \\
\text { Observations }\end{array}$ & Mean & $\begin{array}{c}\text { Standard } \\
\text { Deviation }\end{array}$ & Min & Max \\
& & & & & \\
\hline Fraction of the Married at Age 15 and Above & 165 & 0.57 & 0.06 & 0.43 & 0.68 \\
$\quad$ Total Population & 165 & 0.58 & 0.06 & 0.43 & 0.72 \\
$\quad$ Male & 165 & 0.55 & 0.05 & 0.43 & 0.67 \\
$\quad$ Female & 165 & 0.32 & 0.06 & 0.20 & 0.47 \\
Fraction of the Never-Married at Age 15 and Above & 165 & 0.35 & 0.06 & 0.22 & 0.52 \\
$\quad$ Total Population & 165 & 0.30 & 0.07 & 0.17 & 0.45 \\
$\quad$ Male & & & & & \\
$\quad$ Female & 150 & 0.03 & 0.03 & $0.10 \times 10^{-3}$ & 0.12 \\
Fraction of the Divorced at Age 15 and Above & 150 & 0.02 & 0.03 & $0.05 \times 10^{-3}$ & 0.10 \\
$\quad$ Total Population & 150 & 0.03 & 0.03 & $0.10 \times 10^{-3}$ & 0.13 \\
$\quad$ Male & & & & & \\
$\quad$ Female & 158 & 0.08 & 0.01 & 0.06 & 0.13 \\
Fraction of the Widowed at Age 15 and Above & 158 & 0.04 & 0.01 & 0.02 & 0.07 \\
$\quad$ Total Population & 158 & 0.12 & 0.02 & 0.07 & 0.19 \\
$\quad$ Male & & & & & \\
$\quad$ Female & 165 & 0.13 & 0.11 & 0.01 & 0.51 \\
Sectoral Shares & 165 & 0.34 & 0.07 & 0.17 & 0.53 \\
$\quad$ Agricultural Share & 165 & 0.53 & 0.10 & 0.25 & 0.74 \\
$\quad$ Manufacturing Share & 165 & 8961 & 6264 & 1155 & 26829 \\
$\quad$ Service Share & & & & &
\end{tabular}

Note: In the above table, the number of observations of the fraction of the divorced series and that of the fraction of the widowed series are both less than that of the fraction of the married series. This is because the number of the divorced and the number of the widowed are not always available in some countries, and thus we couldn't construct the numbers.

Sectoral Share We use cross-country data of value-added sectoral shares from Buera and Kaboski (2012b). They construct historical time series data for nominal value-added shares of three broad sectors, agriculture, manufacturing and services, over the twentieth century for all countries in our sample except Finland. For Finland, we collect the data from Herrendorf, Rogerson, and Valentinyi (2014). The shares represent the relative extent of each sector's economic activities in the whole economy. ${ }^{7}$

\subsection{Summary Statistics}

Table 1 describes summary statistics of our data set. The top row shows that the fraction of the married in the total population at age 15 and above varies between 0.43 percent and 0.68 percent in our sample. If we compare the fraction of the married across genders, the fraction of married men ( 0.58 percent) is somewhat higher than that of married women ( 0.55 percent). This difference across genders reflects the biological fact that there are more women in the

\footnotetext{
${ }^{7}$ Sectoral employment shares are another measure of structural transformation. However, the historical data are scarce compared to the nominal value-added share.
} 
economy because women tend to live longer than men. In addition to the fraction of the married, we also report the fraction of the never-married, the fraction of the divorced, and the fraction of the widowed in the total population at age 15 and above. Furthermore, there are three value-added share variables which we use in our analysis (agriculture, manufacturing, and services). These variables also exhibit considerable variation: the agricultural share ranges from 0.01 percent to 0.51 percent. The manufacturing share ranges from 0.17 to 0.53 percent, while the service share goes from 0.25 to 0.74 percent. In the final row, we also report real GDP per capita (1155 to 26829). This shows a large variation, reflecting the fact that most of the countries in our sample achieved significant economic development over the last century.

\subsection{Adjustment of the Age Structure}

In the data, we observe that older people are more likely to be married than younger people. Therefore, changes in the age structure of the population, which have occurred in most of the countries over the twentieth century, can potentially affect the fraction of the married population over time. ${ }^{8}$ In order to control for these effects, we construct a new time series, by assuming that the age structure of the population in each year is the same as the one in the base year, $2000 .^{9}$

More specifically, suppose that the data on marital status is collected by $J$ age groups in each period in country $i$. Also, let $x_{i, t}$ denote the total population, $x_{i, t}^{j}$ the total population in the $j$-th age group, and $m_{i, t}^{j}$ the number of the married in the $j$-th age group, all variables in period $t$. Then, country $i$ 's fraction of the married in year $t$, after keeping the age structure as in 2000 , is obtained as

$$
F_{i t}=\sum_{j=1}^{J}\left(\frac{m_{i, t}^{j}}{x_{i, t}^{j}} \times \frac{x_{i, 2000}^{j}}{x_{i, 2000}}\right) .
$$

The constructed series is used for the robustness check on our results later. ${ }^{10}$ Similar methods are applied for the fraction of the never-married and for the fraction of the divorced.

\footnotetext{
${ }^{8}$ The age structure of population has changed due to several reasons. For instance, baby booms occurred in many of OECD countries in the mid-twentieth century, and life expectancy has improved dramatically during the second half of the twentieth century. Moreover, the majority of countries in our sample experienced war(s) at the beginning and/or in the middle of the twentieth century.

${ }^{9}$ Using a different base year yields similar results. However, for some countries in our sample we miss some years at the beginning of the sample. As 2000 is available for all countries, we use this year as the base.

${ }^{10}$ For the U.K., the year 1900, the structure of reported age groups is significantly different from other years. Therefore, we cannot construct the age-adjusted numbers for this observation.
} 
Figure 1 - Fraction of the Married, Age 15+, OECD Countries, 1900-2000
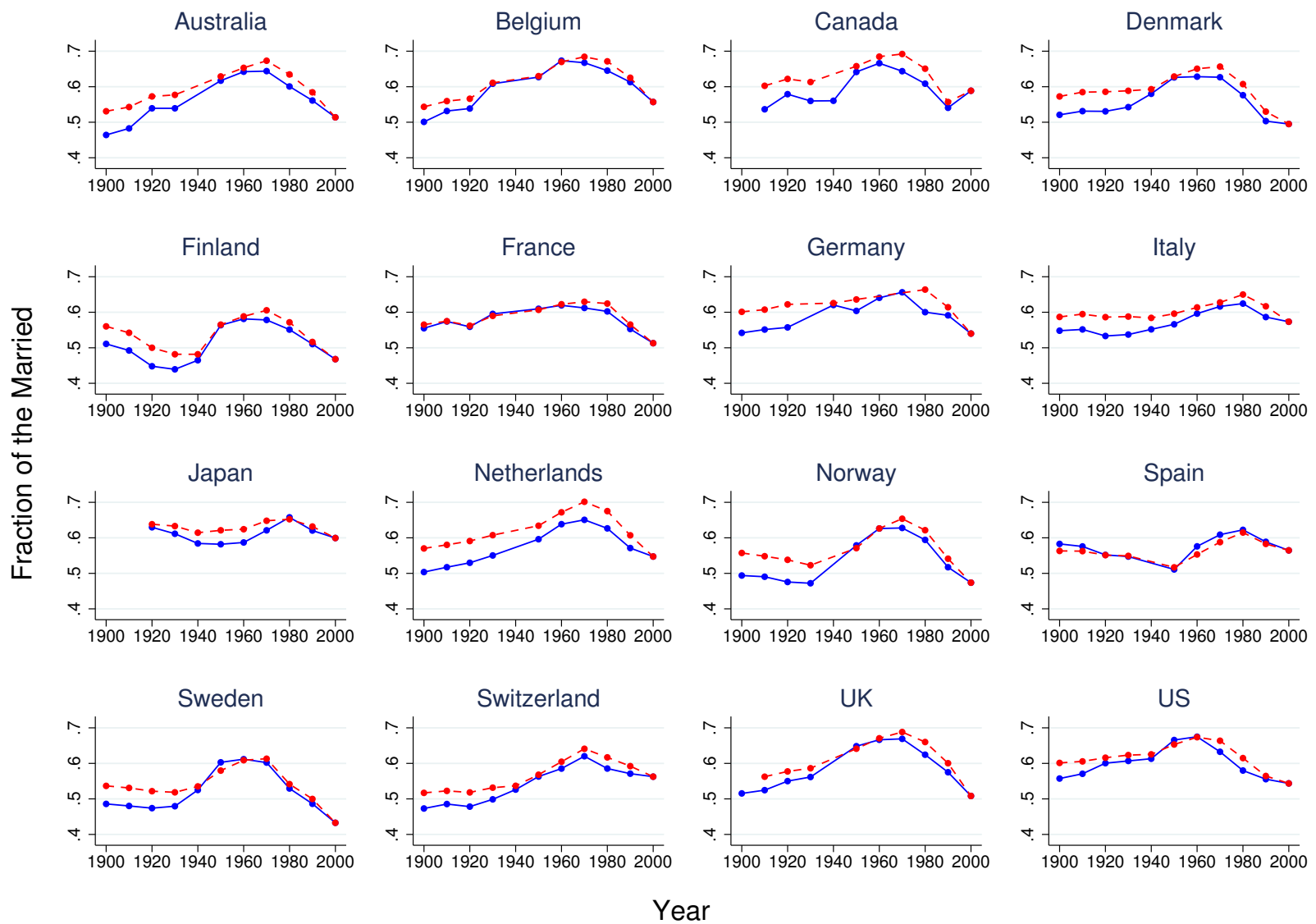

Note: The blue/solid line is for the original sequence. The red/dashed line is for the age-adjusted one.

\section{Empirical Analysis}

This section is devoted to analyzing the relationship between marriage and economic development. We first discuss the evolution of the married, the never married and the divorced in the 16 OECD countries. Next, we investigate the relationship between marriage and economic development.

\subsection{Evolution of Marriage in OECD Countries, 1900-2000}

Married Figure 1 shows the fraction of married in total population at age 15 and above for the raw data (blue/solid line) and for the age-adjusted data (red/dashed line), for the 16 OECD countries in our sample. For the majority of countries, the fraction of the married rises in the early and mid-twentieth century, peaks between 1960 and 1980, and decreases thereafter. As shown in Figure 1, the hump-shaped pattern of the prevalence of marriage is robust for the most of the countries even after controlling for the age-structure of the 
TABlE 2 - Changes in Fraction of the Married at Age 15+

\begin{tabular}{|c|c|c|c|c|c|c|c|c|}
\hline Country & \multicolumn{2}{|c|}{$\begin{array}{c}\text { Value at } \\
\text { the Peak (Year) } \\
(1)\end{array}$} & \multicolumn{2}{|c|}{$\begin{array}{c}\text { Lowest before } \\
\text { the Peak (Year) } \\
(2)\end{array}$} & \multicolumn{2}{|c|}{$\begin{array}{c}\text { Lowest after } \\
\text { the Peak (Year) } \\
(3)\end{array}$} & $\begin{array}{c}\Delta \% \text { Points } \\
\text { to the Peak } \\
\qquad(4)\end{array}$ & $\begin{array}{c}\Delta \% \text { Points } \\
\text { from the Peak } \\
(5)\end{array}$ \\
\hline Australia & 0.64 & (1970) & 0.46 & $(1900)$ & 0.51 & $(2000)$ & 0.18 & -0.13 \\
\hline Belgium & 0.67 & (1960) & 0.50 & $(1900)$ & 0.56 & $(2000)$ & 0.17 & -0.12 \\
\hline Canada & 0.67 & (1960) & 0.54 & $(1910)$ & 0.54 & $(1990)$ & 0.13 & -0.13 \\
\hline Denmark & 0.63 & (1960) & 0.52 & $(1900)$ & 0.50 & $(2000)$ & 0.11 & -0.13 \\
\hline Finland & 0.58 & (1960) & 0.44 & (1930) & 0.47 & $(2000)$ & 0.14 & -0.11 \\
\hline France & 0.62 & (1960) & 0.56 & (1900) & 0.51 & $(2000)$ & 0.06 & -0.11 \\
\hline Germany & 0.66 & (1970) & 0.54 & $(1900)$ & 0.54 & $(2000)$ & 0.11 & -0.12 \\
\hline Italy & 0.62 & (1980) & 0.53 & (1920) & 0.57 & $(2000)$ & 0.09 & -0.05 \\
\hline Japan & 0.66 & (1980) & 0.58 & $(1950)$ & 0.60 & $(2000)$ & 0.08 & -0.06 \\
\hline Netherlands & 0.65 & (1970) & 0.50 & (1900) & 0.55 & $(2000)$ & 0.15 & -0.10 \\
\hline Norway & 0.63 & (1970) & 0.47 & $(1930)$ & 0.47 & $(2000)$ & 0.16 & -0.15 \\
\hline Spain & 0.62 & $(1980)$ & 0.51 & $(1950)$ & 0.56 & $(2000)$ & 0.11 & -0.06 \\
\hline Sweden & 0.61 & (1960) & 0.47 & $(1920)$ & 0.43 & $(2000)$ & 0.14 & -0.18 \\
\hline Switzerland & 0.62 & (1970) & 0.47 & (1900) & 0.56 & $(2000)$ & 0.15 & -0.06 \\
\hline U.K. & 0.67 & (1970) & 0.52 & (1900) & 0.51 & $(2000)$ & 0.15 & -0.16 \\
\hline U.S. & 0.68 & $(1960)$ & 0.56 & (1900) & 0.54 & $(2000)$ & 0.12 & -0.13 \\
\hline
\end{tabular}

population. ${ }^{11}$ For some countries, the rise and fall in marital unions in the age-adjusted data is slightly less pronounced than in the raw data.

Changes in the Married Table 2 summarizes the information on the changes in the fraction of the married over the last century for each country in our sample. The table reports the peak of the fraction of the married (and the year it happened), the lowest value before and after the peak (and the year it happened), as well as the difference between the peak and the lowest values before and after the peak. As reported in Columns (4) and (5), there is some variation across countries in the magnitude of the changes in the fraction of the married. Countries like Australia, Belgium, and Norway witnessed the largest increase in the fraction of the married up to the peak (more than 16 percentage points). Other countries experienced an increase of 6 to 15 percentage points. In France, Italy, and Japan, the increase in the fraction of the married was less than 9 percentage points. Regarding the decline from the peak, in countries such as Norway, Sweden, and the U.K., the fraction of the married decreased by more than 15 percentage points after the peak. Other countries experienced a decline of 5 to 13 percentage points.

Never-Married Figure 2 reports the fraction of the never married in total population at age 15 and above. As in Figure 1, the raw data is given by the blue/solid line and the

\footnotetext{
${ }^{11}$ In Appendix B, we show the time series data of the fraction of married for men and women. Again the hump-shaped pattern is observed for both series for the majority of countries.
} 
Figure 2 - Fraction of the Never-Married, Age 15+, OECD Countries, 1900-2000
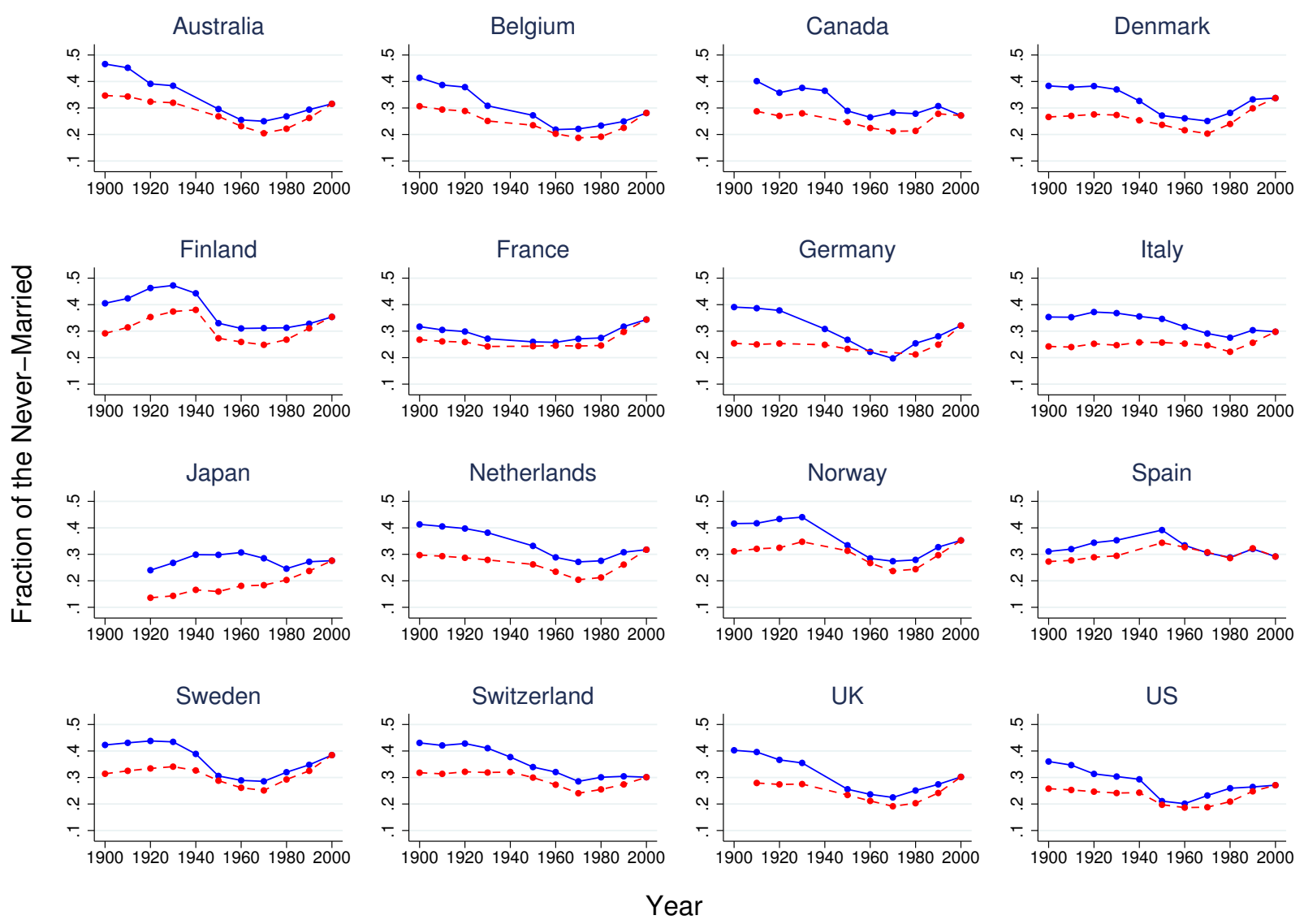

Note: The blue/solid line is for the original sequence. The red/dashed line is for the age-adjusted one.

age-adjusted data by the red/dashed line. For most countries a weakly U-shaped pattern is observed and this is robust even when controlling for the age structure. Loosely speaking, for most countries the pattern of the fraction of the never married looks like the mirror image of the fraction of the married, although the magnitude of the changes is different.

Divorced Figure 3 reports the fraction of the divorced (plus the separated) in total population at age 15 and above. For all countries, except Japan, divorces increase significantly in the second half of the last century, while before 1950 the increase is modest. Some countries display almost no variation in divorces for most of the 20th century. For instance, the data show no trend in Australia until 1950, in Canada until 1960, and in Italy and in the U.K. until 1970. Japan displays a slightly pronounced U-shape, but this country shows almost no variation over the century.

By taking together the information in Figures 2 and 3, it appears that the increasing part 
Figure 3 - Fraction of the Divorced, Age 15+, OECD Countries, 1900-2000
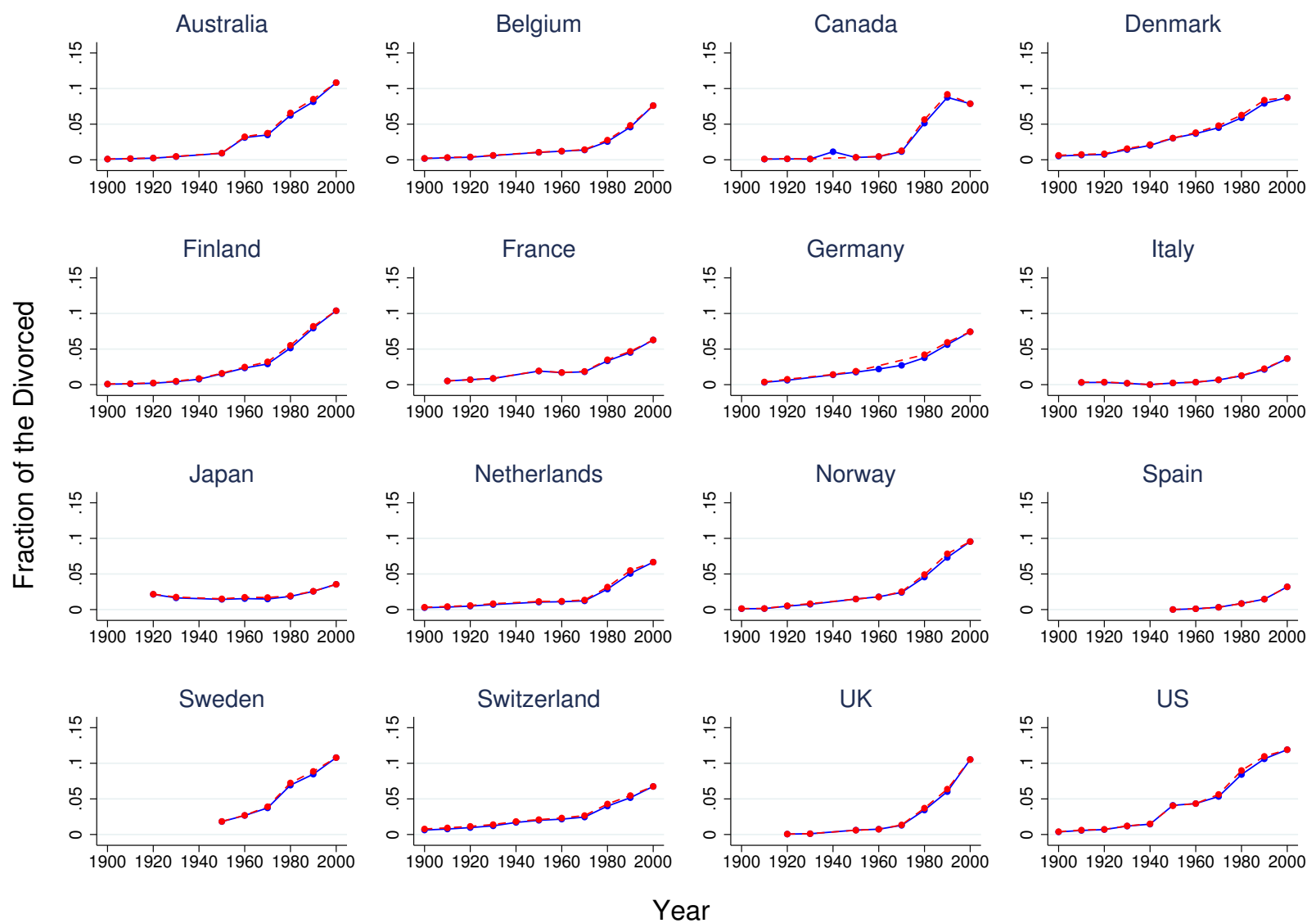

Note: The blue/solid line is for the original sequence. The red/dashed line is for the age-adjusted one.

of the hump of the fraction of the married is mainly driven by the decline in the fraction of the never married. On the other hand, the decreasing part of the hump is due to the combination of the the decline in the fraction of the never-married and the increase in that of the divorced.

\subsection{Marriage and Economic Development}

Methodology To study the relationship between marriage and economic development, we first follow the approach in Buera and Kaboski (2012b) to control for country-specific effects in each data series. That is, we regress each data series (the fraction of married in total population at age 15 and above, and the value-added share of each sector) on a cubic function of log of real GDP per capita with country dummies as follows:

$$
s_{i, t}=\Phi\left(\log \left[r e a l_{-} G D P \_p e r \_c a p i t a\right]\right)+D_{i}+\epsilon_{i, t},
$$


Figure 4 - Fraction of the Married, Age 15+, by GDP Per Capita, OECD Countries, $1900-2000$

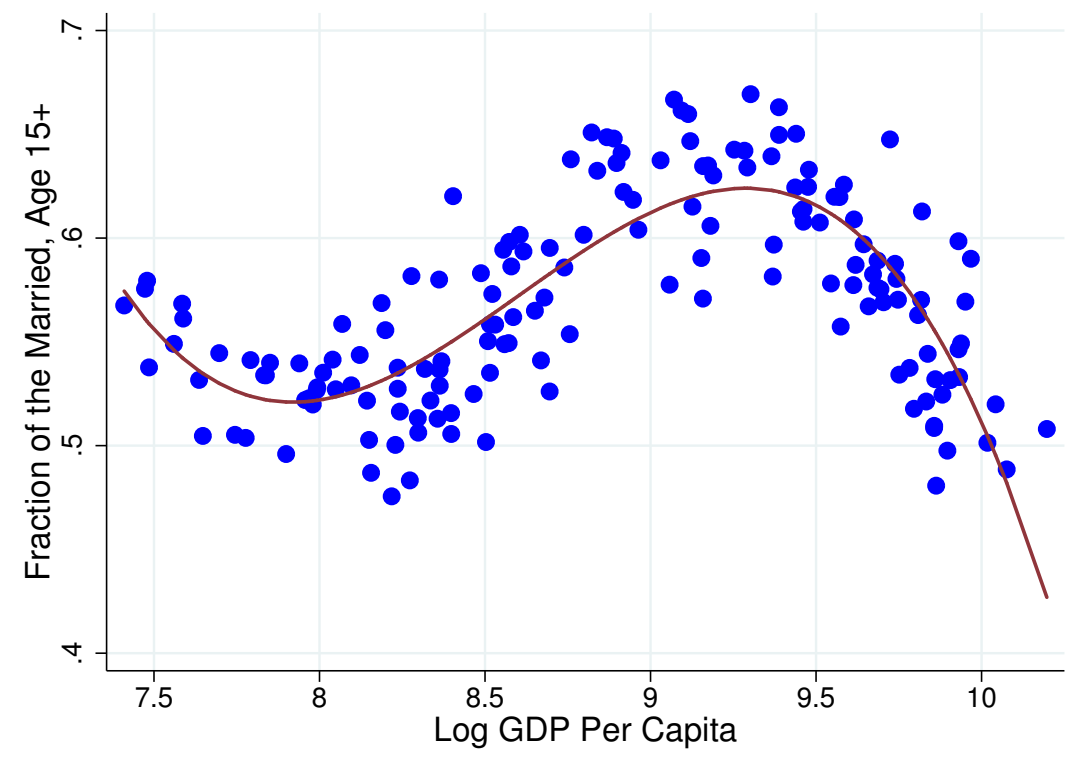

where $\Phi(\cdot)$ is a cubic polynomial, $s_{i, t}$ denotes the value of each data series for country $i$ in period $t, D_{i}$ is country $i$ 's dummy to capture the country-specific effect, and $\epsilon_{i, t}$ is an error term. Then, we subtract the estimated country-fixed effects from the raw data.

In order to confirm that our results don't depend on the choice of the specific functional form in (1), we also use a nonparametric plot. Specifically, we apply a kernel smoothed local linear regression with a rule of thumb bandwidth. ${ }^{12}$

Evolution of Marriage on the Economic Growth Path Figure 4 reports the relationship between the fraction of the married and log real GDP per capita, controlling for country-fixed effects. The evolution of marriage displays a clear hump-shaped pattern as the income level increases. From the level of log GDP per capita of around 8 to 9.25, there is an increase in the fraction of married people, followed by a steep decline. At the level of log GDP per capita of around 10, the fraction of married is at a similar level as it is for a $\log$ GDP per capita of around 8. While the decline in the fraction of married in the last decades is a well documented fact, the evidence on the systematic increase in marriages occurring at lower levels of income as GDP grows, is novel.

Although Figure 4 shows a clear hump-shaped pattern of the fraction of the married, such a pattern can be due to the fact that we are using raw marriage data, which are exposed to changes in the age structure, or that we are employing a particular econometric methodology. Therefore, we check that our finding is robust to various treatments. In Figure 5, we first

\footnotetext{
${ }^{12}$ For details about a kernel regression, see Cameron and Trivedi (2005) for example.
} 
Figure 5 - Fraction of the Married by GDP Per Capita, OECD Countries, 1900-2000
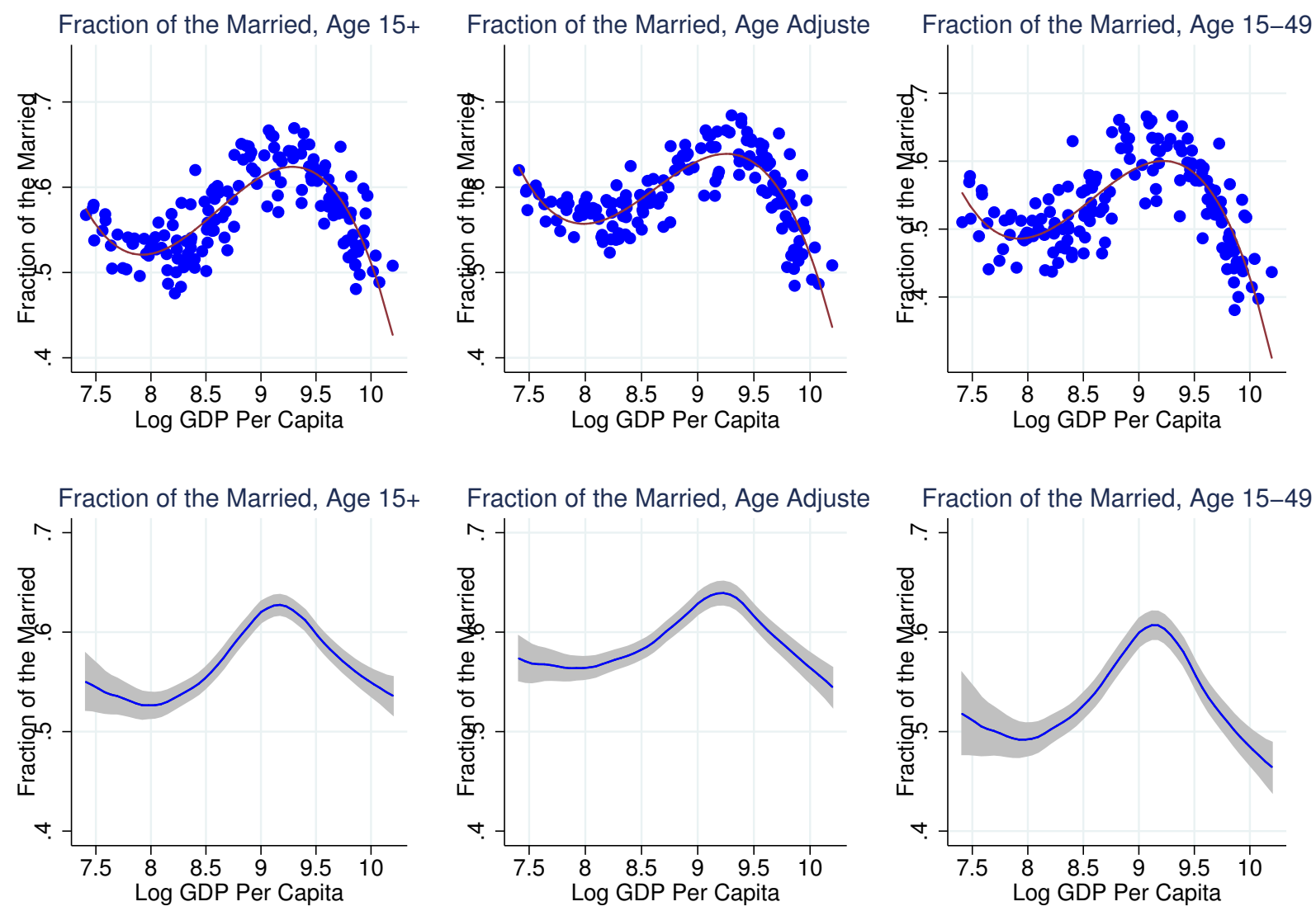

Note: In the bottom 3 panels, gray areas indicate 95 percent confidence intervals.

consider the age-adjusted measure of the fraction of the married, because a change in the structure of the population can, per se, increase the fraction of the married. The top-middle panel reports the relationship of the age-adjusted fraction of the married with log GDP per capita. The resulting pattern is very close to the one shown from the raw data, displayed in the top-left panel for comparison. Next, we consider the population between 15 and 49 years old, in order to shut down the effect of the changes in life expectancy. This is reported in the top-right panel of Figure 5. Again, the resulting relationship is very close to the one in the top-left panel. It is important to note that, in all three figures, the top of the hump-shape coincides with a level of log GDP per capita of 9.25.

Next, we address a potential methodological issue. It is possible that the hump-shaped pattern of the fraction of the married is due to the particular cubic relationship that we assume when we control for fixed effects. In the bottom panels of Figure 6, we report the results of nonparametric plots of the fraction of the married against log GDP per capita. 
Figure 6 - Scatter Plots of Fraction of the Married and Sectoral Shares by GDP Per Capita (Fixed Effects Controlled), OECD Countries, 1900-2000
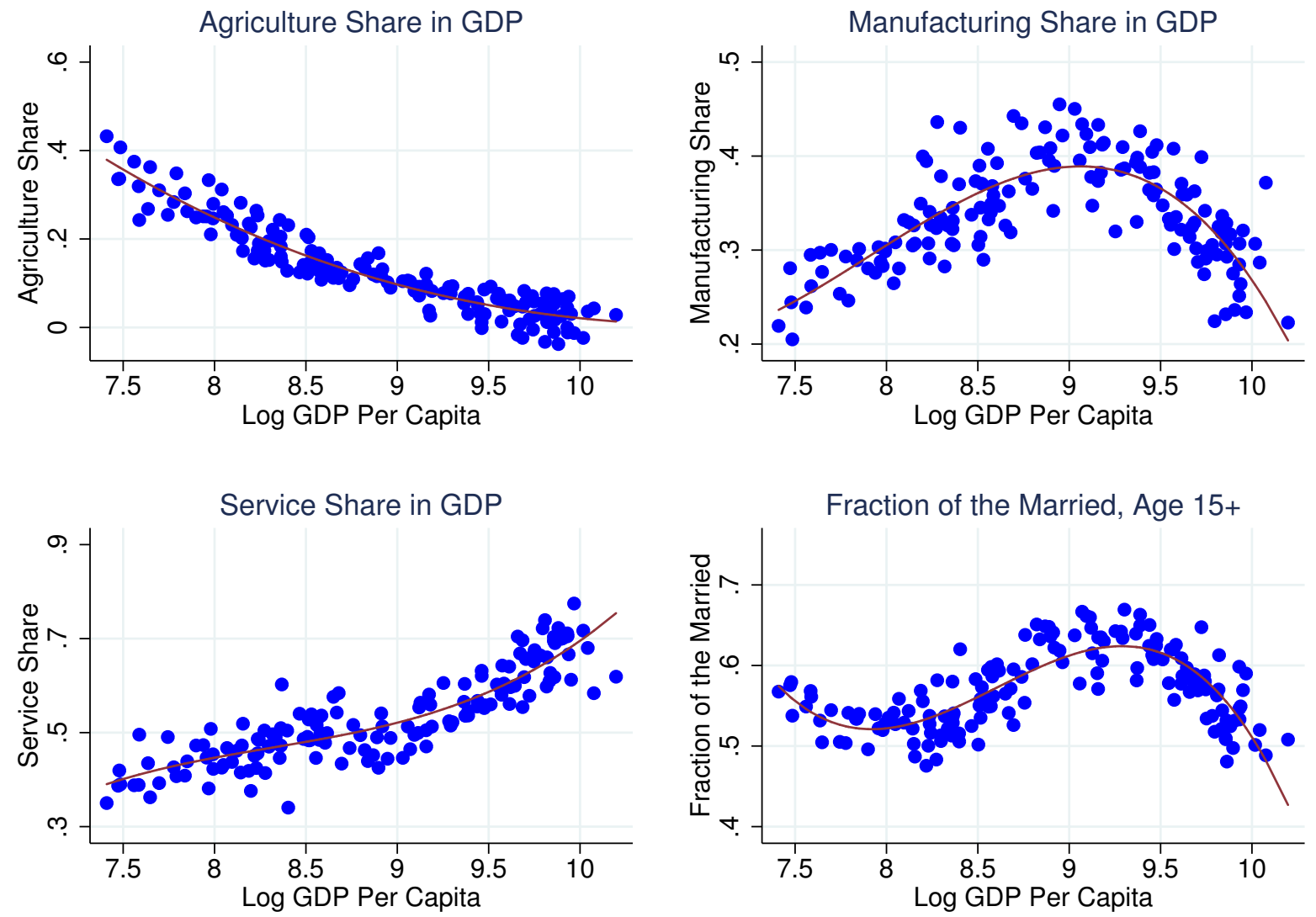

For the three different measures of the fraction of the married, raw, age-adjusted, and aged 15-49, the estimation provides a clear hump-shaped relationship. Also, the top of the hump again coincides with a level of log GDP of 9.25.

Marriage and Industrial Structure In the previous subsection, we showed how the fraction of the married evolves as GDP per capita grows. However, GDP growth is a synthetic measure of economic activities, and does not provide information on distributional changes of income over the development path, especially between men and women. ${ }^{13}$ If economic opportunities for the two sexes improve in different ways as GDP grows, marital incentives of individuals might also be affected, as many previous studies pointed out. ${ }^{14}$ In-

\footnotetext{
${ }^{13}$ Economic theories which explain how the sectoral composition affects relative income of men and women are provided by Galor and Weil (1996), Rendall (2010), Ngai and Petrongolo (2015), and Rendall (2014). Empirical evidence is documented in Rendall (2013), Olivetti and Petrongolo (2014), and Olivetti (2014).

${ }^{14}$ For how changes in economic opportunities alter gains of marriage from specialization and change individuals' incentives to marry, see Becker (1973), Lam (1988), Chade and Ventura (2002), and Regalia, Ríos-Rull, and Short (2011) among others.
} 
Figure 7 - Nonparametric Plots of Fraction of the Married and Sectoral Shares by GDP Per Capita, OECD Countries, 1900-2000
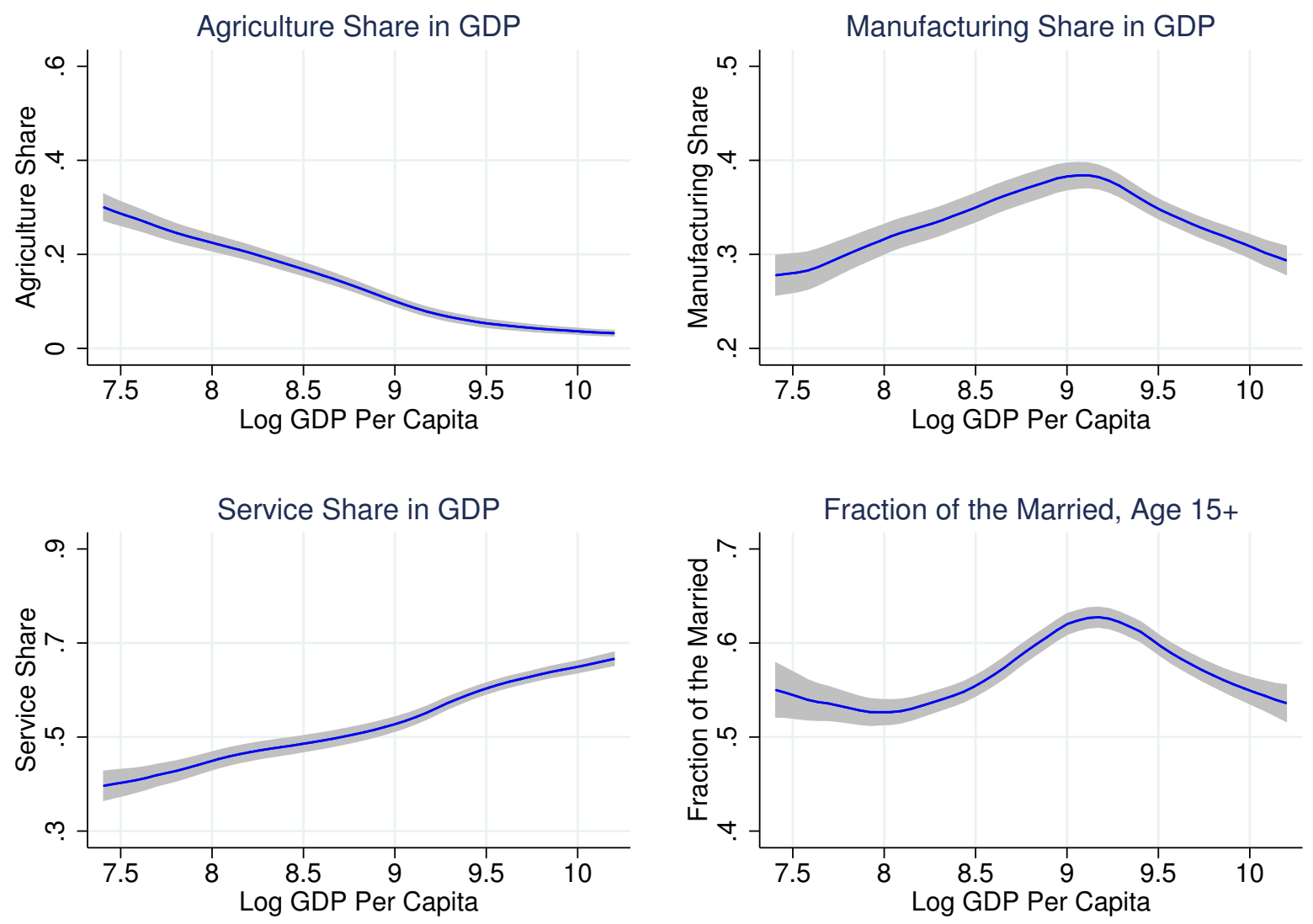

Note: Gray areas indicate 95 percent confidence intervals.

deed, Goldin (1995) argues that, relative to men, women appear to be historically barred from the manufacturing sector, due to social norms or employer preferences. Thus, with a rise of manufacturing as a share of GDP, women might work more at home and less in the market, experiencing a decline in the average wage relative to men. ${ }^{15}$ On the other hand, with the modern rise of the services sectors, the female labor force participation rate and wages soar, as described in Ngai and Petrongolo (2015). Therefore, it seems natural to analyze how marriage relates to changes in sectoral shares in GDP (structural transformation) that occur as GDP grows. ${ }^{16}$

To investigate if there is a relationship between structural transformation and marriage, in Figure 6 we report the evolution of the GDP share of the three broad sectors (agricul-

\footnotetext{
${ }^{15}$ In related work, we show that the process of structural transformation is tightly linked to the amount of labor devoted to work at home. See Moro, Moslehi, and Tanaka (2015)

${ }^{16}$ For how sectoral shares change as an economy grows, see Buera and Kaboski (2012b) and Herrendorf, Rogerson, and Valentinyi (2014) among many others.
} 
TABLE 3 - Correlation between Fraction of Married and Manufacturing Share

\begin{tabular}{lc}
\hline $\begin{array}{l}\text { Fraction of Married } \\
\text { (for different age structure) }\end{array}$ & $\begin{array}{c}\text { Correlation with } \\
\text { Manufacturing Share }\end{array}$ \\
\hline Age 15+ & 0.49 \\
Age 15+, adjusted & 0.46 \\
Age 15-49 & 0.49 \\
\hline
\end{tabular}

ture, manufacturing, and services) against log GDP per capita, after controlling for countryspecific fixed effects. ${ }^{17}$ The figure shows that, as countries become richer, the importance of agriculture in the economy shrinks, while that of services increases. The manufacturing sector instead, displays a hump-shaped pattern.

In the bottom-right panel of Figure 6, we report the fraction of the married in the population at age 15 and above. Notably, the graph displays a behavior that is similar to that of the manufacturing sector. In particular, the peak of the estimated curve is found at the same level of log GDP per capita both for marriage and for manufacturing. The pattern is more evident if we look at the results of the nonparametric plot shown in Figure 7. To confirm this finding, in Table 3, we report the correlation statistics between manufacturing share and the fraction of the married. The correlation is 0.49 when considering the raw data. The second and the third rows show the resulting correlation when we use the age-adjusted series and the series for the population aged 15-49. These results also confirm that there is a positive correlation between the manufacturing share and the fraction of the married. ${ }^{18}$

Thus, our results on marriage appear to be consistent with the theory described in Goldin (1995). As income grows, the structure of the economy benefits men and women in different ways. This, in turn, affects incentives to marry. Interestingly, it seems that the fraction of the married is large when economic possibilities of the two sexes are different (that is, when manufacturing is the dominant sector in the economy) while they are small when such possibilities are similar (either agriculture or services is the dominant sector).

\section{Conclusion}

In this paper, we provided a newly constructed data set on marriage rates across countries and over time that is suitable for quantitative analysis. To our knowledge, this is the most comprehensive data set on marriage available for OECD countries. Our data span the entire twentieth century, during which time several social, technological, economic, institutional

\footnotetext{
${ }^{17}$ The method to control fixed effects is similar to the one we earlier applied for the fraction of the married.

${ }^{18}$ In Appendix C, we run a regression analysis, and find that this positive correlation between manufacturing share and the fraction of the married is robust even after controlling for several other factors.
} 
and demographic changes took place, including world shocks such as the two great wars. Thus, our data set is potentially suitable to analyze the relationship between marriage and several social changes, allowing researchers to control for individual countries' idiosyncratic conditions.

We used this data set to analyze the relationship between marriage and economic development. Although there is a large body of literature that discusses the role of economic conditions to account for changes in marriage over the development path, no study could provide a quantitative assessment of this relationship. Our quantitative results shed light on the effect of sectoral composition in the economy on family formation.

We have shown that the fractions of the married displays a clear hump-shaped pattern as income grows. One interpretation of such a non-monotonic relationship is that, as GDP grows, the distribution of income becomes more even or uneven between the two genders. As economic status of men and women are a key factor in marital decisions, the fraction of the married can move following a change in the gender distribution of income. A well known factor that can affect such distribution is the process of structural transformation. The idea is that some sectors of the economy (namely the manufacturing sector) favor male labor relative to female labor, so a rise of the value-added share of these sectors in the economy can affect the distribution of income between men and women. This being the case, a relationship between structural transformation and marriage should be clearly observable.

To investigate this possibility, we used our cross-country data set together with the data on value-added shares of agriculture, manufacturing and services of our 16 OECD countries over the twentieth century. We found a positive relationship between marriage and the manufacturing share. Thus, we conclude that our results indicate that the structure of the economy is a key determinant of the pattern of marriage observed in OECD countries in the last century. 


\section{References}

Abramitzky, R., A. Delavande, and L. Vasconcelos (2011): "Marrying up: the Role of Sex ratio in Assortative Matching," American Economic Journal: Applied Economics, pp. 124-157.

Angrist, J. (2002): "How Do Sex Ratios Affect Marriage and Labor Markets? Evidence from America's Second Generation," Quarterly Journal of Economics, pp. 997-1038.

Becker, G. S. (1973): "A Theory of Marriage: Part I," The Journal of Political Economy, 81(4), 813-846.

(1981): A Treatise on the Family. Harvard University Press.

Buera, F. J., And J. Kaboski (2012a): "The Rise of the Service Economy," American Economic Review, 102(6), 2540-2569.

Buera, F. J., And J. P. Kaboski (2012b): "Scale and the Origins of Structural Change," Journal of Economic Theory, 147(2), 684-712.

Cameron, A. C., and P. K. Trivedi (2005): Microeconometrics: Methods and Applications. Cambridge University Press.

Chade, H., and G. Ventura (2002): "Taxes and Marriage: A Two-Sided Search Analysis," International Economic Review, 43(3), 955-985.

Chesnais, J.-C. (1992): The Demographic Transition: Stages, Patterns, and Economic Implications. Clarendon Press.

Chiappori, P.-A., B. Salanié, and Y. Weiss (2015): "Partner Choice and the Marital College Premium: Analyzing Marital Patterns over Several Decades," Working Paper.

Fernández, R., N. Guner, and J. Knowles (2005): "Love and Money: A Theoretical and Empirical Analysis of Household Sorting and Inequality," Quarterly Journal of Economics, 120(1), 273-344.

Galor, O., and D. N. WeIl (1996): "The Gender Gap, Fertility, and Growth," American Economic Review, 86(3), 374-87.

Goldin, C. (1995): "The U-Shaped Female Labor Force Function in Economic Development and Economic History," in Investment in Women's Human Capital and Economic Development. University of Chicago Press. 
Greenwood, J., And N. Guner (2008): "Marriage and Divorce since World War II: Analyzing the Role of Technological Progress on the Formation of Households," NBER Macroeconomics Annual, 23(1), 231-276.

Greenwood, J., N. Guner, and J. A. Knowles (2003): "More on Marriage, Fertility, and the Distribution of Income," International Economic Review, 44(3), 827-862.

Greenwood, J., N. Guner, G. Kocharkov, and C. Santos (forthcoming): "Technology and the Changing Family: A Unified Model of Marriage, Divorce, Educational Attainment and Married Female Labor-Force Participation," American Economic Journal: Macroeconomics.

Herrendorf, B., R. Rogerson, and Á. Valentinyi (2013): "Two Perspectives on Preferences and Structural Transformation," American Economic Review, 103(7), 27522789.

(2014): "Growth and Structural Transformation," Handbook of Economic Growth, $2,855-941$.

Iyigun, M., And J. Lafortune (2015): "Why Wait? A Century of Education, Marriage Timing and Gender Roles," Working Paper.

LAM, D. (1988): "Marriage Markets and Assortative Mating with Household Public Goods: Theoretical Results and Empirical Implications," Journal of Human Resources, 23(4), 462487.

LundströM, H. (1999): Befolkningsutvecklingen under 250 År: Historisk Statistik för Sverige. Statistiska Centralbyrån.

Maddison, A. (2005): "Measuring and Interpreting World Economic Performance 15002001," Review of Income and Wealth, 51(1), 1-35.

Minnesota Population Center (2014): "Integrated Public Use Microdata Series, International: Version 6.3 [Machine-readable database]," Minneapolis: University of Minnesota.

Mitchell, B. (2007): International Historical Statistics 1750-2005. Palgrave Macmillan.

Moro, A., S. Moslehi, and S. Tanaka (2015): "Does Home Production Drive Structural Transformation?," Working Paper.

Ngai, L. R., and B. Petrongolo (2015): "Gender Gaps and the Rise of the Service Economy," Working Paper. 
Ngai, L. R., And C. A. Pissarides (2007): "Structural Change in a Multisector Model of Growth," American Economic Review, 97(1), 429-443.

Olivetti, C. (2014): "The Female Labor Force and Long-Run Development: The American Experience in Comparative Perspective," in Human Capital in History: The American Record, ed. by C. F. L. Platt Boustan, and R. Margo. University of Chicago Press.

Olivetti, C., And B. Petrongolo (2014): "Gender Gaps across Countries and Skills: Demand, Supply and the Industry Structure," Review of Economic Dynamics, 17(4), 842859.

Regalia, F., J.-V. Ríos-Rull, And J. Short (2011): "What Accounts for the Increase in the Number of Single Households?," Working Paper.

Rendall, M. (2010): "Brain versus Brawn: The Realization of Women's Comparative Advantage," Working Paper.

(2013): "Structural Change in Developing Countries: Has It Decreased Gender Inequality?," World Development, 45, 1-16.

— (2014): "The Service Sector and Female Market Work," Working Paper.

Ritzmann-Blickenstorfer, H. (1996): Historische Statistik der Schweiz. ChronosVerlag.

Ruggles, S., K. Genadek, R. Goeken, M. B. Schroeder, and M. Sobek (2015): "Integrated Public Use Microdata Series: Version 6.0 [Machine-readable database]," Minneapolis: University of Minnesota.

Schoen, R., W. Urton, K. Woodrow, and J. Bai (1985): "Marriage and Divorce in Twentieth Century American Cohorts," Demography, 22(1), 101-114.

Stevenson, B., And J. Wolfers (2007): "Marriage and Divorce: Changes and their Driving Forces," The Journal of Economic Perspectives, 21(2), 27-52. 


\section{Supplemental Online Appendix}




\section{A Data Source}

This appendix reports the data sources for each of the OECD countries in our sample. There are seven special cases, which could apply for a country-year observation in Table A.1. These seven cases are as follows.

$(* 1)$ Information on the number of divorced individuals is not available.

- France (1900), Germany (1900), and Sweden (1900-1950) report the number of divorced individuals and that of widowed individuals together. Therefore, we cannot obtain each number.

- Spain (1900-1930), Italy (1900), and the U.K. (1900-1910) don't even have a category of divorced individuals or that of separated individuals.

$(* 2)$ Information on the number of widowed individuals is not available.

(*3) Data have information on the number of individuals who are married but separated.

(*4) Data have information on the number of individuals who are in a consensual union.

$(* 5)$ The married category includes individuals who are in a consensual union.

$(* 6)$ The divorced category includes individuals who are married but separated.

$(* 7)$ Data are based on UNSD's estimates.

In Table A.1 below, we put remarks $(* 1-7)$ to indicate whether each case applies for a country-year observation. 


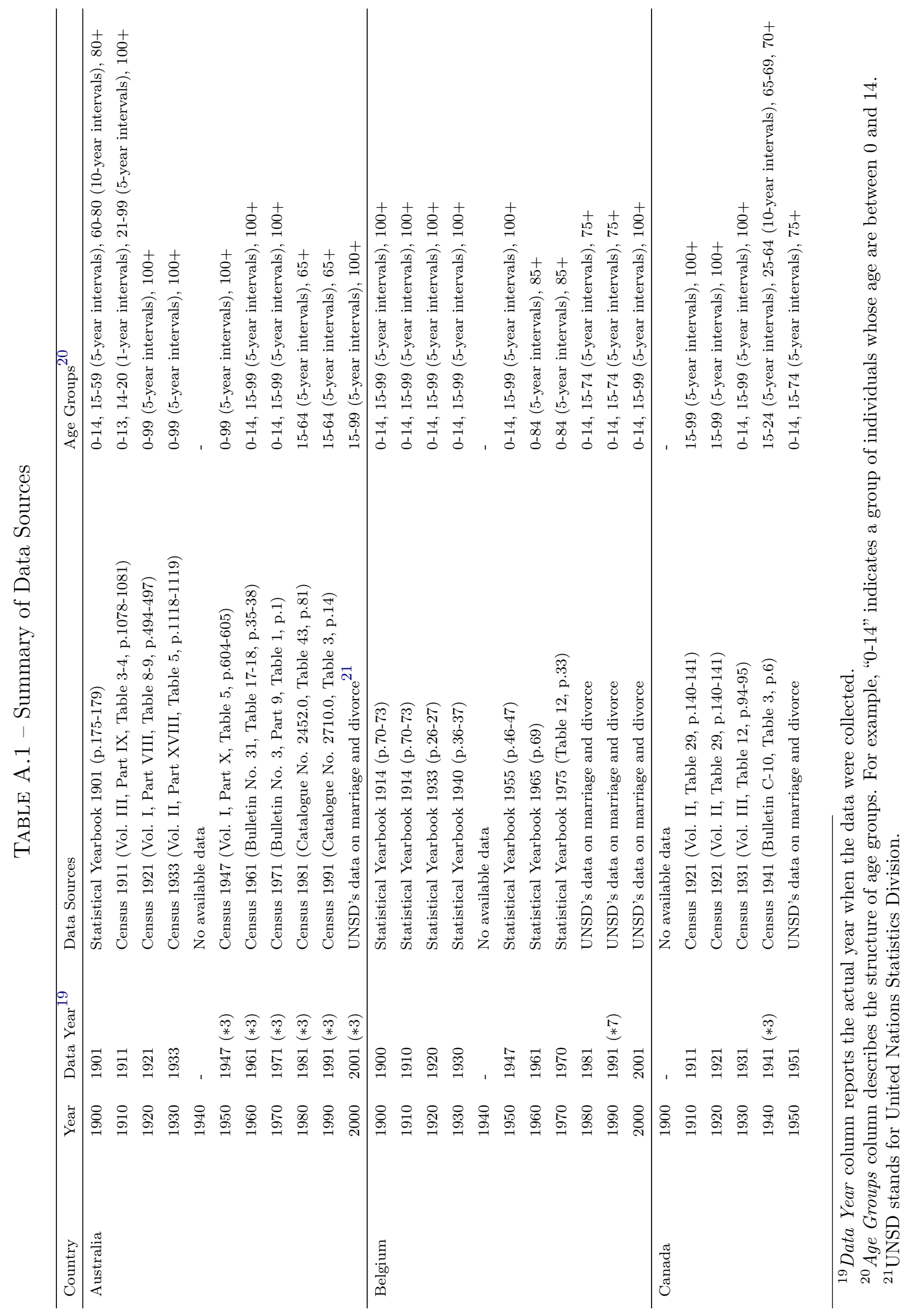




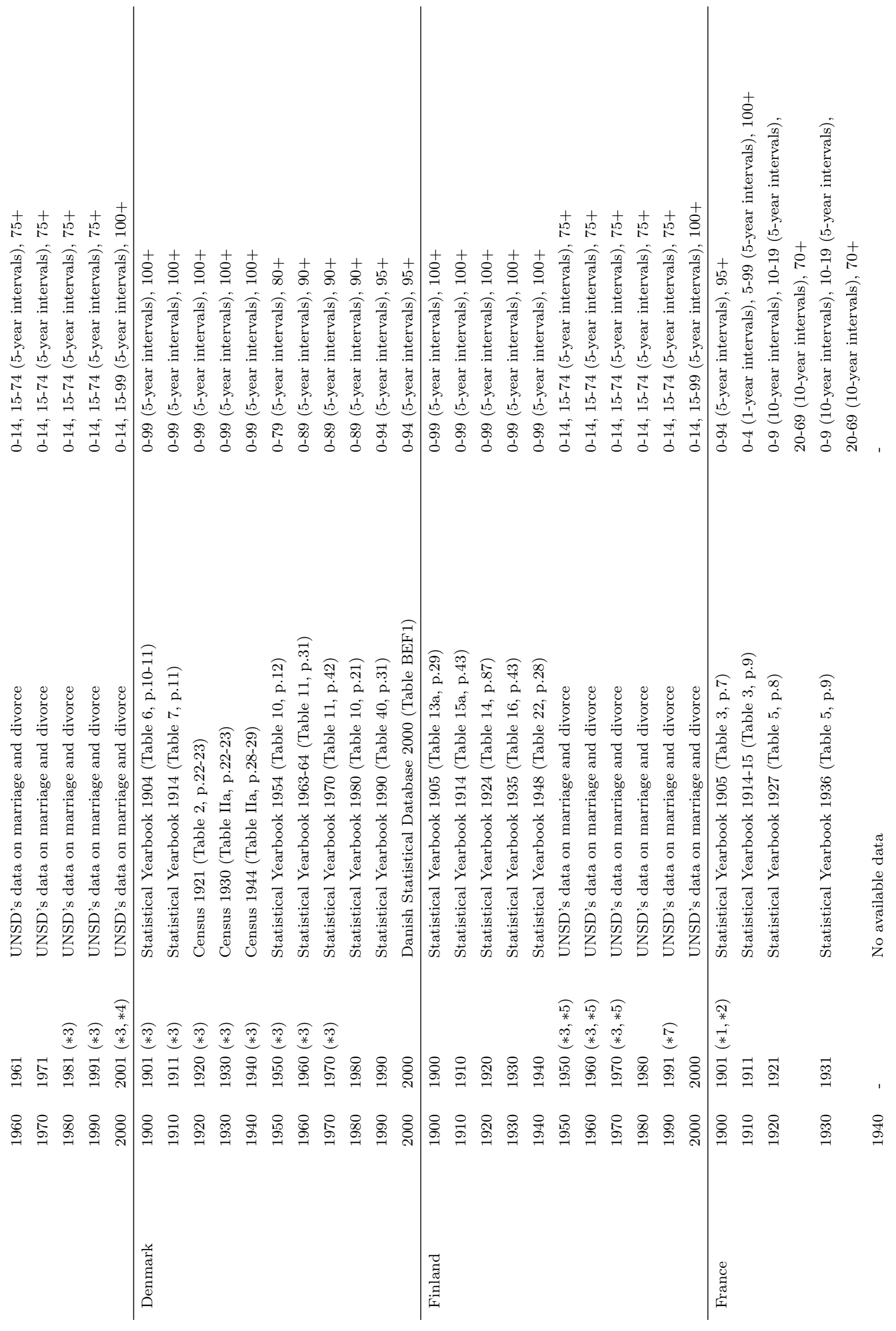




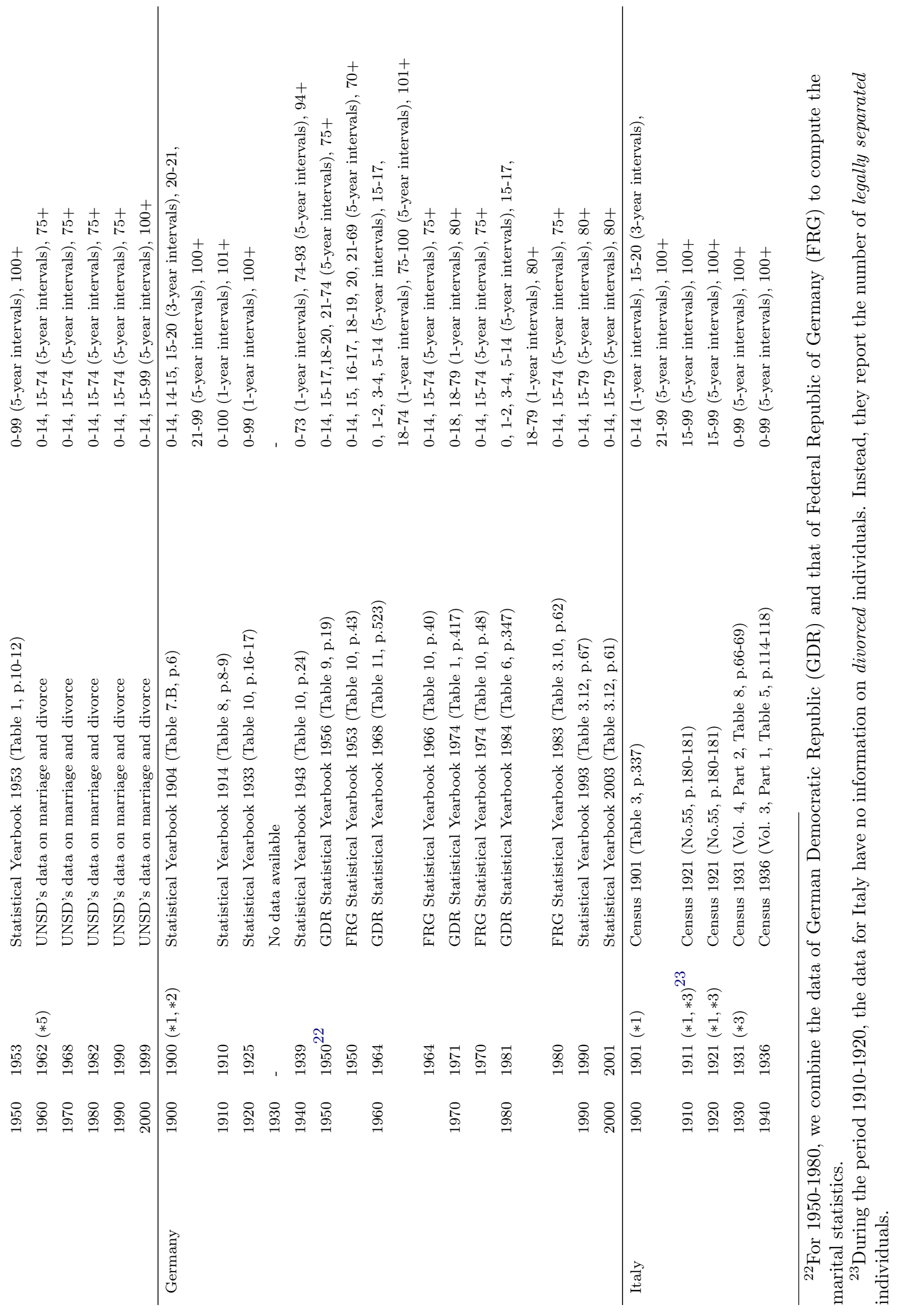




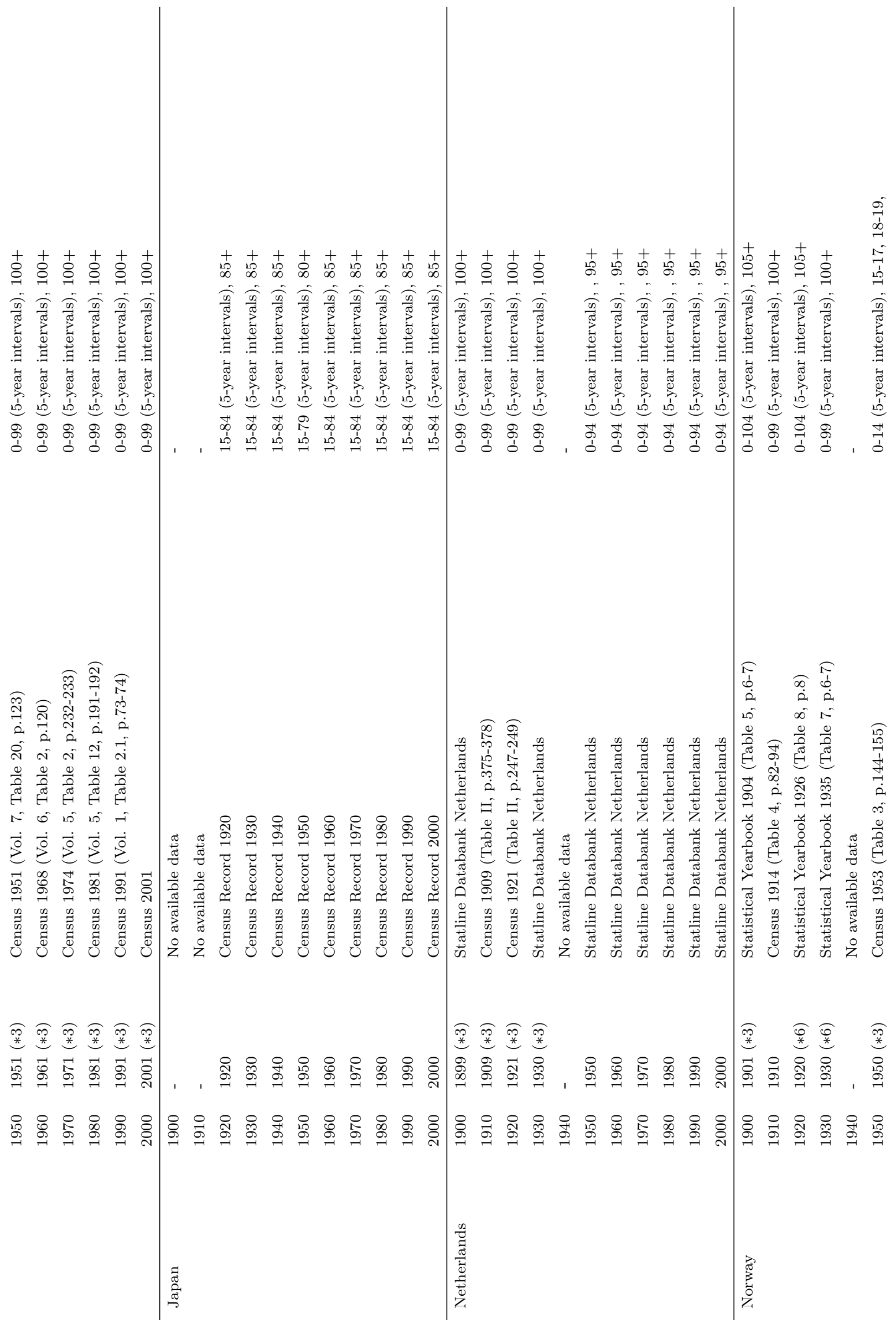




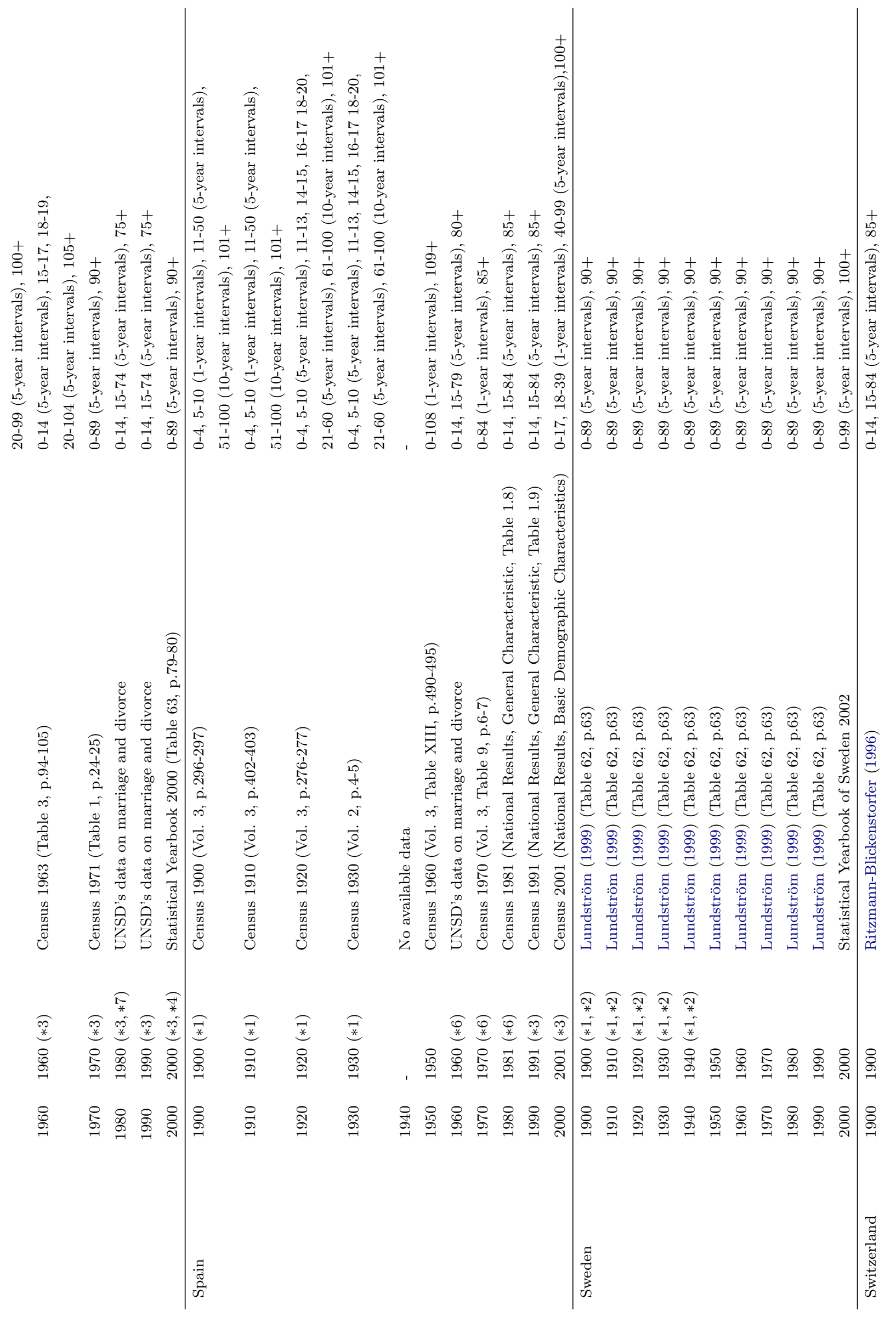




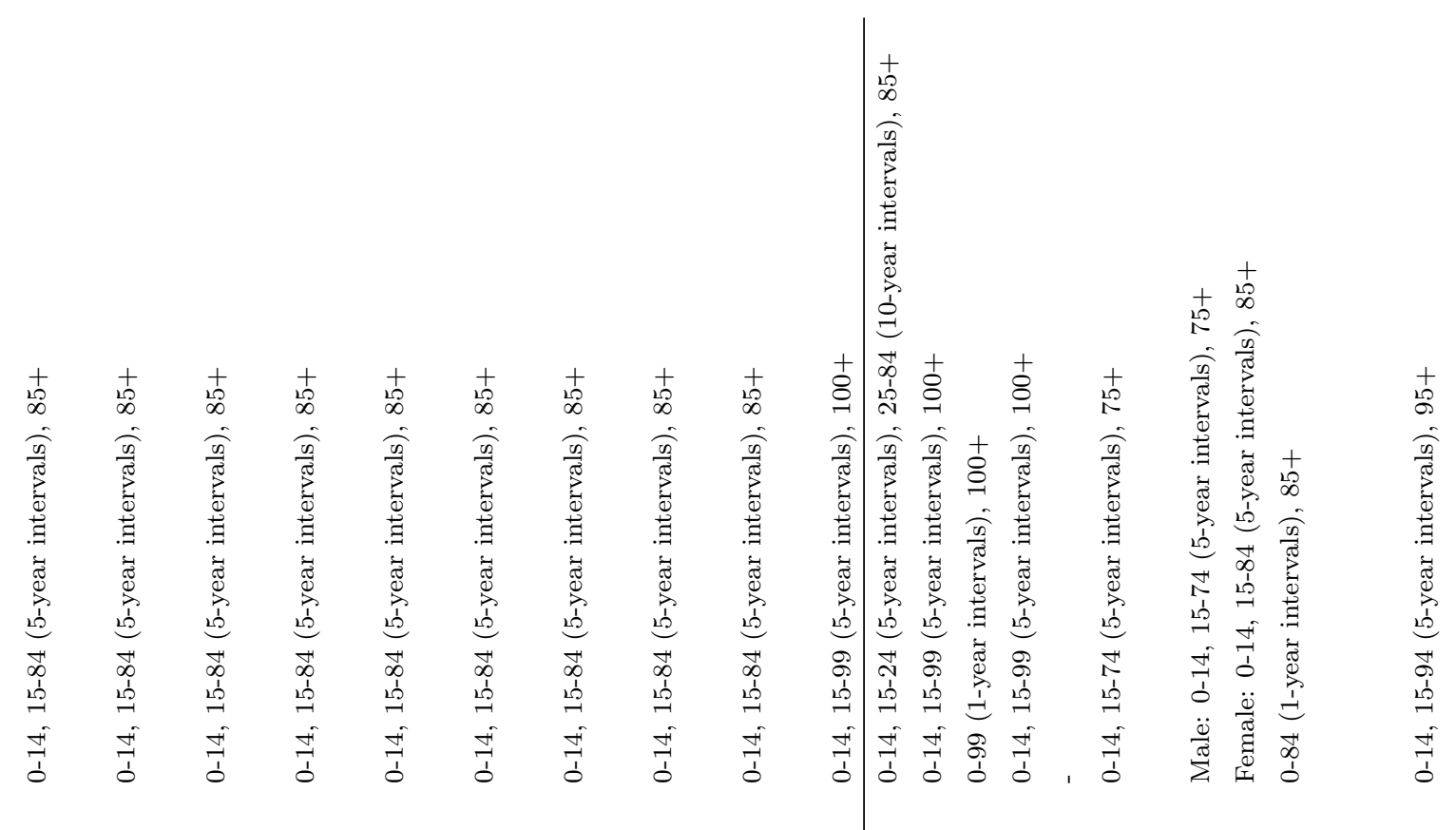

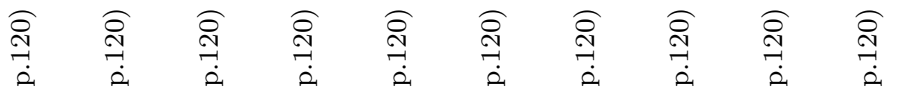

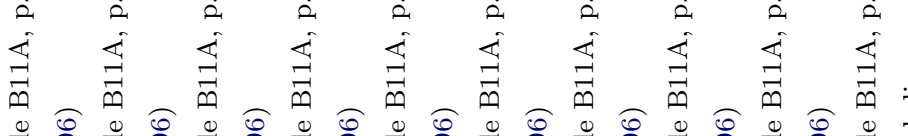

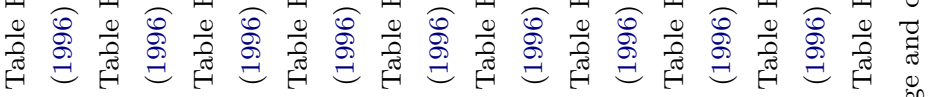

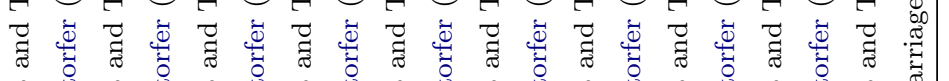

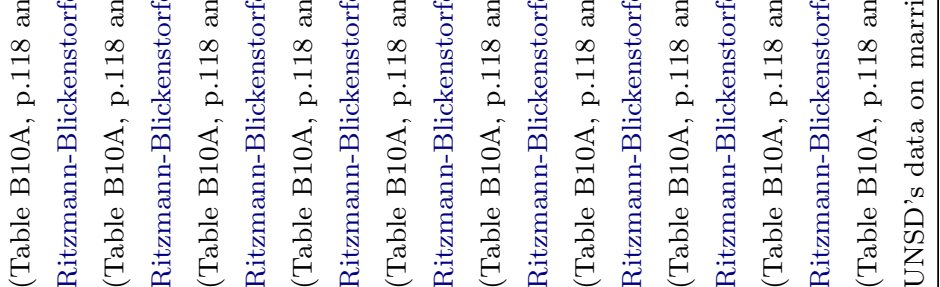

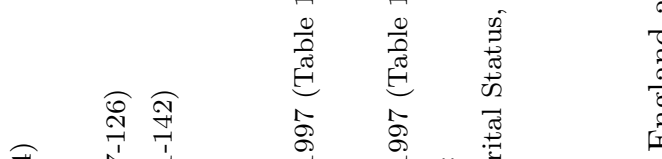

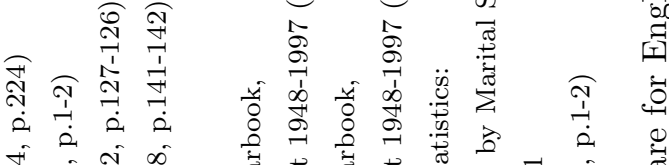

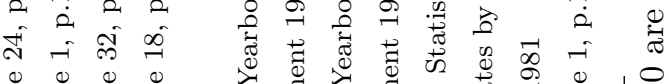
告

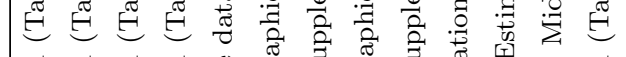

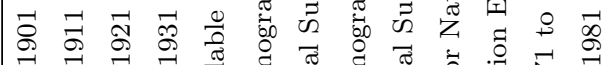

寄 $\frac{\sqrt{2}}{\pi}$

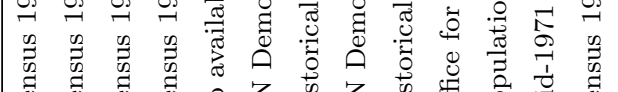

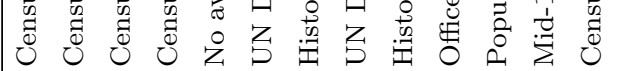

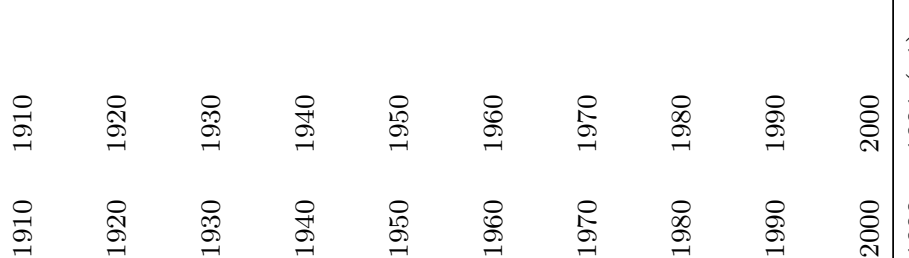

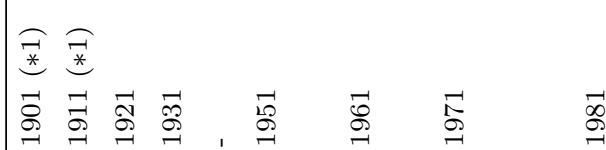

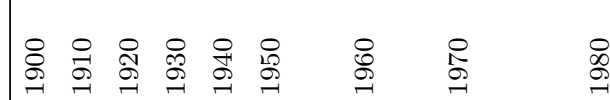

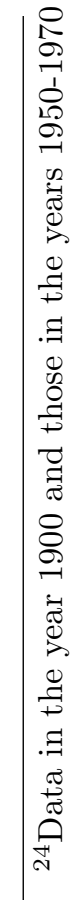




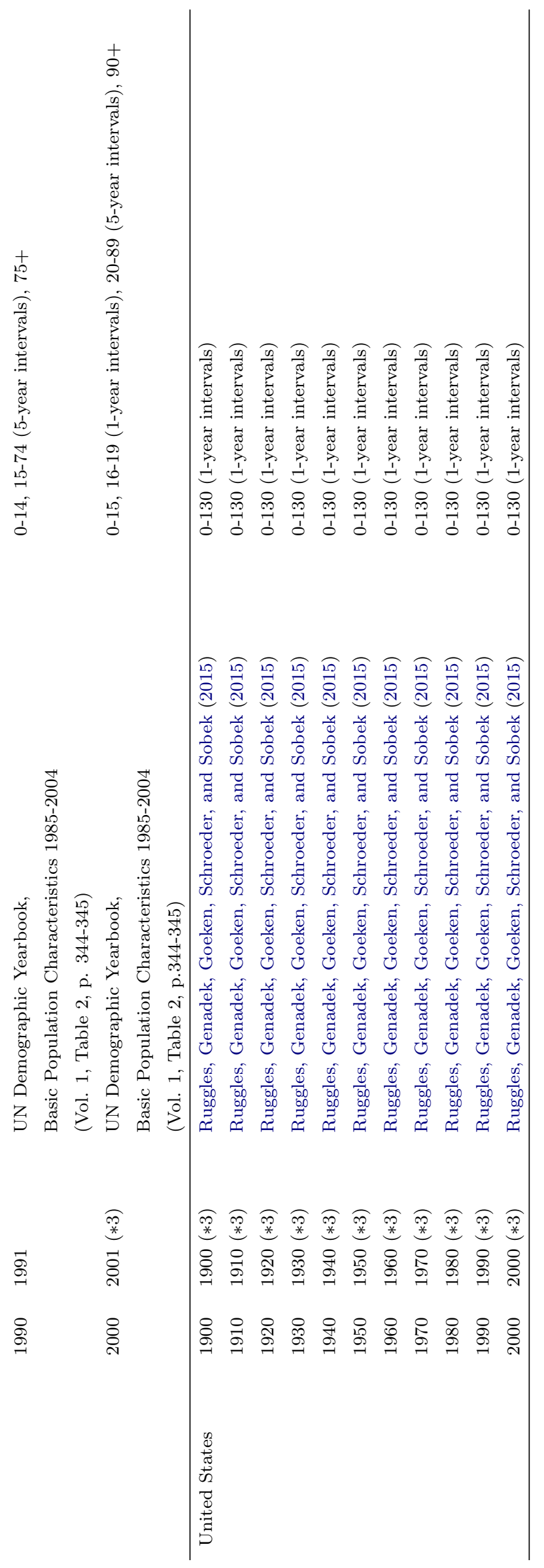




\section{B Marriage Pattern by Sex}

Figure A.1 - Fraction of the Married by Sex, Age 15+, OECD Countries, 1900-2000
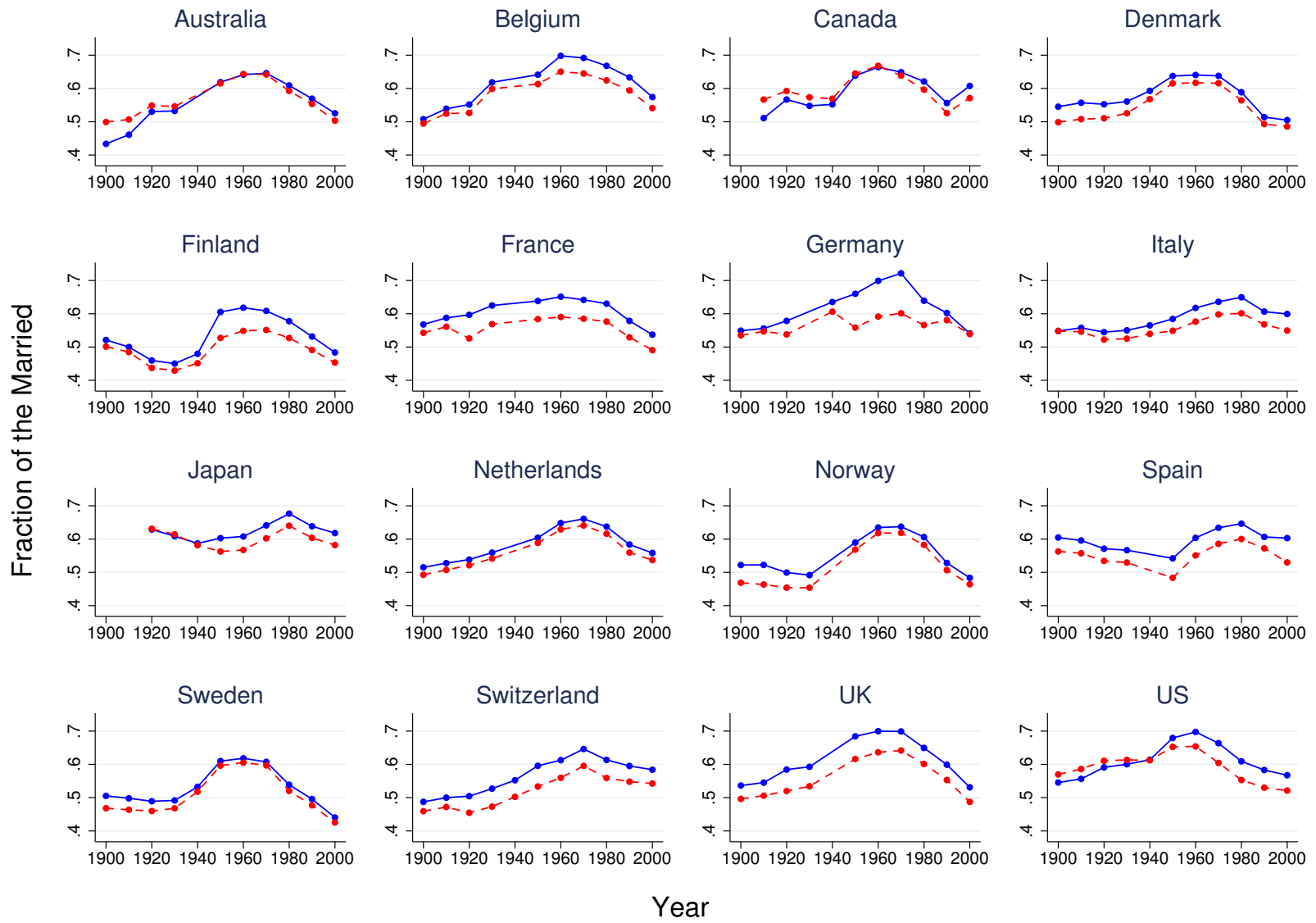

Note: The blue/solid line is the one for males. The red/dashed line is the one for females. 
Figure A.2 - Fraction of the Never-Married by Sex, Age 15+, OECD Countries, $1900-2000$
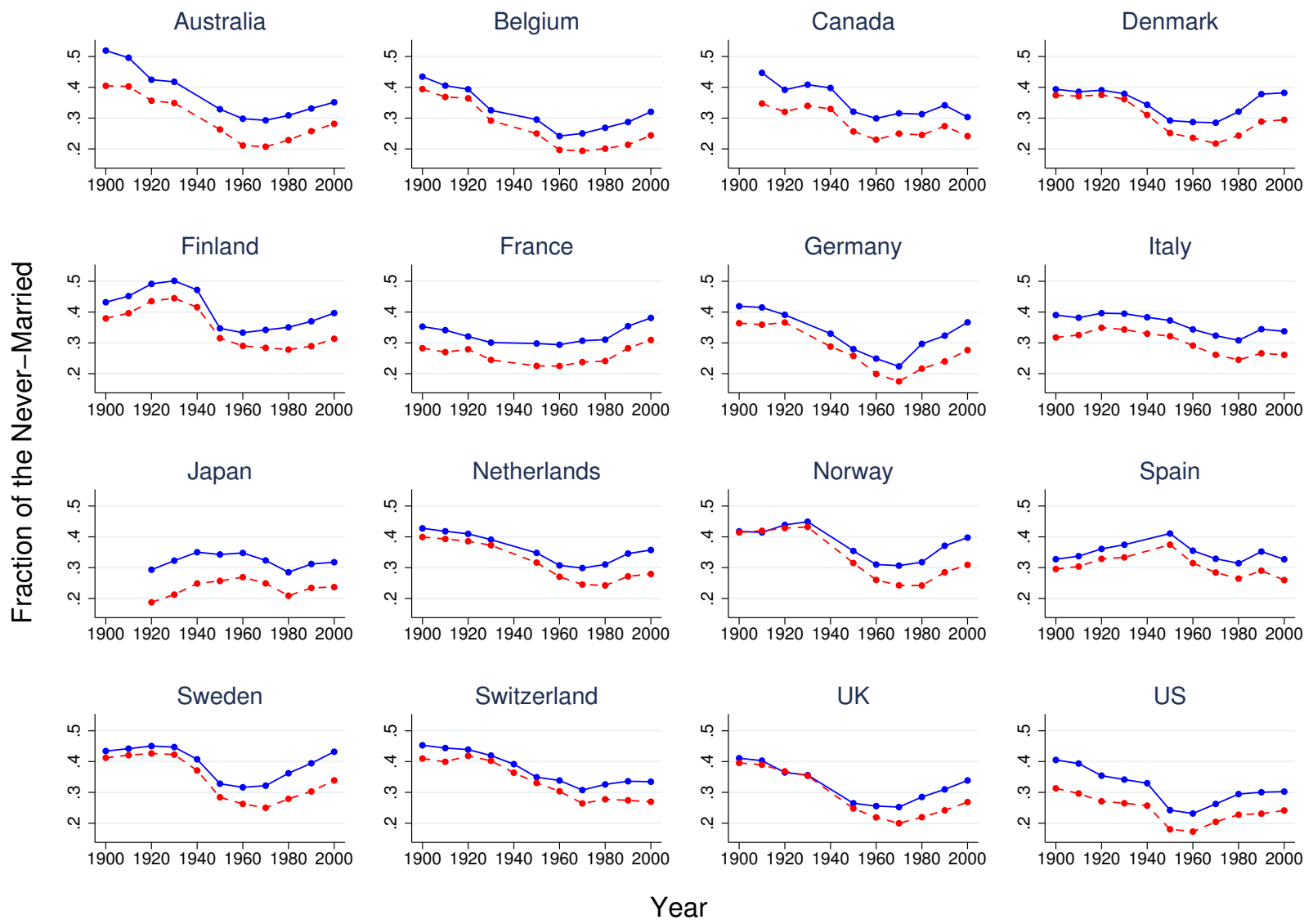

Note: The blue/solid line is the one for males. The red/dashed line is the one for females. 
Figure A.3 - Fraction of the Divorced by Sex, Age 15+, OECD Countries, 1900-2000
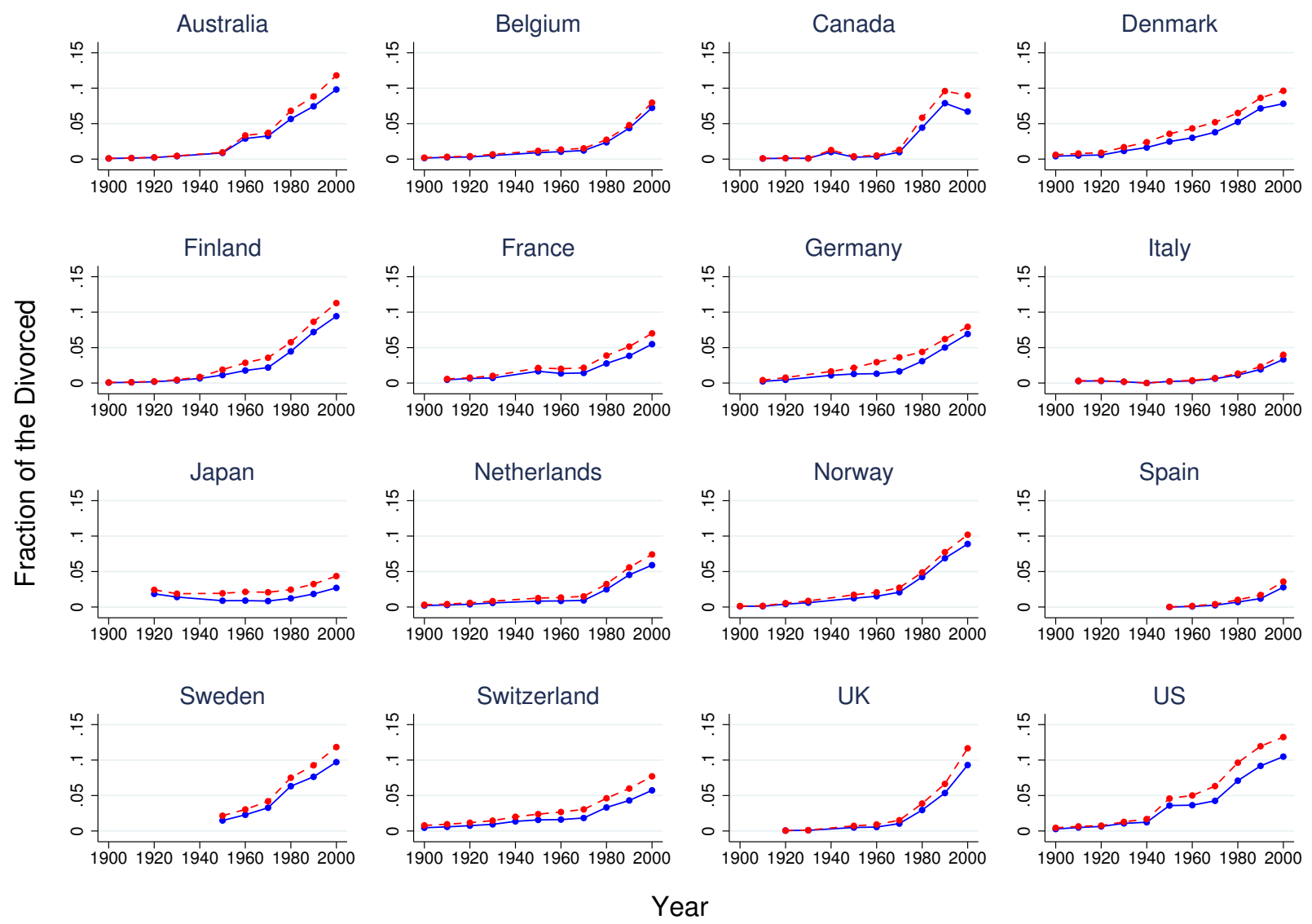

Note: The blue/solid line is the one for males. The red/dashed line is the one for females. 


\section{Regression Analysis}

In this appendix, we investigate whether the positive correlation between the fraction of the married and the manufacturing share is robust after controlling for other variables in the regression analysis. ${ }^{25}$ In the analysis, the dependent variable is the nominal value added share in manufacturing. Similar to the existing literature in this field we employ several control variables: the sex ratio (the ratio of the number of males to the number of females), the total fertility rate, and the crude birth rate. ${ }^{26}$ We control for the sex ratio because sex ratio imbalances can cause an increase or an decrease of marriages as documented in Angrist (2002) and Abramitzky, Delavande, and Vasconcelos (2011). The fertility rate and the crude birth rate are included in our regression analysis as Greenwood, Guner, and Knowles (2003) argue that the decision to get married and to have children are tightly linked.

Table A.2 reports the regression results for the fraction of married men at age 15 and above for the raw data (Columns 1 through 4 ) and the age-adjusted data (Columns 5 through 8), respectively, with or without country fixed effects. Similarly, Table A.3 reports the results of the same regressions for women. The coefficient on the manufacturing share is significant and positive for both men and women in all specifications; for men it ranges between 0.46 and 0.61 , while for women it ranges between 0.39 and 0.55 . If we consider the specification in Column (1) in both Tables, the results imply that one percentage point increase in manufacturing share raises the fraction of married men, by 0.48 percentage points, and fraction of married women by 0.44 percentage points. The results for the sex ratio are consistent with Angrist (2002) and Abramitzky, Delavande, and Vasconcelos (2011). The coefficient of the sex ratio for male's regression is negative for all the specifications and significant at 5 percent level for the five out of all the eight specifications. For women, it is positively significant at 1 percent level for all specifications. Again, if we take the specification in Column (1) in the both tables, the results imply that one percent increase in the sex ratio decreases the fraction of married men by 0.07 percentage points, while it increases the fraction of married women by 0.41 percentage points. Finally, note that the coefficients of the total fertility rate and the crude birth rate often changes their signs, and seem to have only negligible effects on the fraction of the married. These results confirm that the positive correlation between the fraction of the married and the nominal value added share of manufacturing is robust after controlling for other things which could possibly affect marriage.

\footnotetext{
${ }^{25}$ It is worth emphasizing that in our model marriage is endogenous and the purpose of this section is to check the robustness of correlation after controlling for other variables. This correlation does not imply causation.

${ }^{26}$ For the sex ratio, we compute it from census records. For total fertility rate, we combine the data from Chesnais (1992) with the data from World Development Indicators (WDI) at World Bank. For the crude birth rate, the data are from Mitchell (2007). Both the total fertility rate and the crude birth rate are reported annually. Therefore, we average the annual data to obtain decennial data.
} 
TABle A.2 - Regression Results for Men at Age 15 and Above

\begin{tabular}{|c|c|c|c|c|c|c|c|c|}
\hline & $\begin{array}{l}(1) \\
\text { Raw }\end{array}$ & $\begin{array}{l}(2) \\
\text { Raw }\end{array}$ & $\begin{array}{l}\text { (3) } \\
\text { Raw }\end{array}$ & $\begin{array}{c}(4) \\
\text { Raw }\end{array}$ & $\begin{array}{c}(5) \\
\text { Adjusted }\end{array}$ & $\begin{array}{c}(6) \\
\text { Adjusted }\end{array}$ & $\begin{array}{c}(7) \\
\text { Adjusted }\end{array}$ & $\begin{array}{c}(8) \\
\text { Adjusted }\end{array}$ \\
\hline Manufacturing Share & $\begin{array}{l}0.4796^{* *} \\
(0.0532)\end{array}$ & $\begin{array}{l}0.6065^{* *} \\
(0.0543)\end{array}$ & $\begin{array}{l}0.4643^{* *} \\
(0.0533)\end{array}$ & $\begin{array}{l}0.6021^{* *} \\
(0.0552)\end{array}$ & $\begin{array}{l}0.4814^{* *} \\
(0.0528)\end{array}$ & $\begin{array}{l}0.5534^{* *} \\
(0.0545)\end{array}$ & $\begin{array}{l}0.4724^{* *} \\
(0.0524)\end{array}$ & $\begin{array}{l}0.5484^{* *} \\
(0.0551)\end{array}$ \\
\hline Ln(Sex Ratio 15+) & $\begin{array}{c}-0.0721 \\
(0.0756)\end{array}$ & $\begin{array}{c}-0.1734^{*} \\
(0.0827)\end{array}$ & $\begin{array}{c}-0.1395 \\
(0.0856)\end{array}$ & $\begin{array}{c}-0.2226^{* *} \\
(0.0848)\end{array}$ & $\begin{array}{c}-0.0965 \\
(0.0719)\end{array}$ & $\begin{array}{c}-0.2276^{* *} \\
(0.0816)\end{array}$ & $\begin{array}{c}-0.1682^{*} \\
(0.0823)\end{array}$ & $\begin{array}{c}-0.2692^{* *} \\
(0.0846)\end{array}$ \\
\hline Ln(Total Fertility Rate) & $\begin{array}{c}-0.0203^{\dagger} \\
(0.0116)\end{array}$ & $\begin{array}{c}-0.0222^{*} \\
(0.0099)\end{array}$ & & & $\begin{array}{l}0.0273^{*} \\
(0.0114)\end{array}$ & $\begin{array}{c}0.0271^{* *} \\
(0.0100)\end{array}$ & & \\
\hline Ln(Crude Birth Rate) & & & $\begin{array}{c}-0.0207^{\dagger} \\
(0.0123)\end{array}$ & $\begin{array}{c}-0.0329^{* *} \\
(0.0098)\end{array}$ & & & $\begin{array}{c}0.0319^{* *} \\
(0.0122)\end{array}$ & $\begin{array}{l}0.0247^{*} \\
(0.0103)\end{array}$ \\
\hline Constant & $\begin{array}{l}0.4401^{* *} \\
(0.0217)\end{array}$ & $\begin{array}{l}0.3985^{* *} \\
(0.0217)\end{array}$ & $\begin{array}{l}0.4822^{* *} \\
(0.0421)\end{array}$ & $\begin{array}{c}0.4691^{* *} \\
(0.0338)\end{array}$ & $\begin{array}{l}0.4391^{* *} \\
(0.0220)\end{array}$ & $\begin{array}{c}0.4044^{* *} \\
(0.0232)\end{array}$ & $\begin{array}{l}0.3685^{* *} \\
(0.0428)\end{array}$ & $\begin{array}{c}0.3528^{* *} \\
(0.0376)\end{array}$ \\
\hline Country Fixed Effect & No & Yes & No & Yes & No & Yes & No & Yes \\
\hline $\mathrm{R}$-square & 0.32 & 0.62 & 0.32 & 0.63 & 0.31 & 0.61 & 0.32 & 0.60 \\
\hline $\mathrm{N}$ & 152 & 152 & 155 & 155 & 148 & 148 & 151 & 151 \\
\hline
\end{tabular}

Robust standard errors in parentheses

${ }^{\dagger} p<0.10,{ }^{*} p<0.05,{ }^{* *} p<0.01$

TABle A.3 - Regression Results for Women at Age 15 and Above

\begin{tabular}{|c|c|c|c|c|c|c|c|c|}
\hline & $\begin{array}{l}\text { (1) } \\
\text { Raw }\end{array}$ & $\begin{array}{c}(2) \\
\text { Raw }\end{array}$ & $\begin{array}{l}\text { (3) } \\
\text { Raw }\end{array}$ & $\begin{array}{l}\text { (4) } \\
\text { Raw }\end{array}$ & $\begin{array}{c}(5) \\
\text { Adjusted }\end{array}$ & $\begin{array}{c}(6) \\
\text { Adjusted }\end{array}$ & $\begin{array}{c}(7) \\
\text { Adjusted }\end{array}$ & $\begin{array}{c}(8) \\
\text { Adjusted }\end{array}$ \\
\hline Manufacturing Share & $\begin{array}{l}0.4368^{* *} \\
(0.0492)\end{array}$ & $\begin{array}{l}0.5464^{* *} \\
(0.0527)\end{array}$ & $\begin{array}{l}0.4227^{* *} \\
(0.0495)\end{array}$ & $\begin{array}{l}0.5422^{* *} \\
(0.0540)\end{array}$ & $\begin{array}{l}0.4065^{* *} \\
(0.0532)\end{array}$ & $\begin{array}{l}0.4636^{* *} \\
(0.0539)\end{array}$ & $\begin{array}{l}0.3929^{* *} \\
(0.0530)\end{array}$ & $\begin{array}{l}0.4609^{* *} \\
(0.0555)\end{array}$ \\
\hline $\operatorname{Ln}($ Sex Ratio $15+)$ & $\begin{array}{l}0.4090^{* *} \\
(0.0726)\end{array}$ & $\begin{array}{c}0.3210^{* *} \\
(0.0809)\end{array}$ & $\begin{array}{l}0.3424^{* *} \\
(0.0821)\end{array}$ & $\begin{array}{l}0.2696^{* *} \\
(0.0839)\end{array}$ & $\begin{array}{l}0.4879^{* *} \\
(0.0736)\end{array}$ & $\begin{array}{l}0.2817^{* *} \\
(0.0847)\end{array}$ & $\begin{array}{c}0.4373^{* *} \\
(0.0743)\end{array}$ & $\begin{array}{c}0.2505^{* *} \\
(0.0817)\end{array}$ \\
\hline Ln(Total Fertility Rate) & $\begin{array}{c}-0.0114 \\
(0.0111)\end{array}$ & $\begin{array}{c}-0.0135 \\
(0.0096)\end{array}$ & & & $\begin{array}{c}-0.0206^{*} \\
(0.0100)\end{array}$ & $\begin{array}{c}-0.0176^{\dagger} \\
(0.0090)\end{array}$ & & \\
\hline Ln(Crude Birth Rate) & & & $\begin{array}{l}-0.0120 \\
(0.0116)\end{array}$ & $\begin{array}{c}-0.0230^{*} \\
(0.0093)\end{array}$ & & & $\begin{array}{c}-0.0205^{\dagger} \\
(0.0108)\end{array}$ & $\begin{array}{c}-0.0272^{* *} \\
(0.0090)\end{array}$ \\
\hline Constant & $\begin{array}{l}0.4423^{* *} \\
(0.0197)\end{array}$ & $\begin{array}{l}0.4082^{* *} \\
(0.0215)\end{array}$ & $\begin{array}{l}0.4667^{* *} \\
(0.0388)\end{array}$ & $\begin{array}{l}0.4573^{* *} \\
(0.0328)\end{array}$ & $\begin{array}{l}0.4672^{* *} \\
(0.0206)\end{array}$ & $\begin{array}{l}0.4565^{* *} \\
(0.0220)\end{array}$ & $\begin{array}{c}0.5091^{* *} \\
(0.0386)\end{array}$ & $\begin{array}{l}0.5176^{* *} \\
(0.0335)\end{array}$ \\
\hline Country Fixed Effect & No & Yes & No & Yes & No & Yes & No & Yes \\
\hline R-square & 0.30 & 0.60 & 0.27 & 0.58 & 0.31 & 0.61 & 0.28 & 0.60 \\
\hline $\mathrm{N}$ & 152 & 152 & 155 & 155 & 148 & 148 & 151 & 151 \\
\hline
\end{tabular}

Robust standard errors in parentheses

${ }^{\dagger} p<0.10,{ }^{*} p<0.05,{ }^{* *} p<0.01$ 